\title{
23. CENOZOIC DIATOM BIOSTRATIGRAPHY AND PALEOCEANOGRAPHY OF THE WESTERN EQUATORIAL INDIAN OCEAN ${ }^{1}$
}

\author{
Naja Mikkelsen²
}

\begin{abstract}
Sites 705-716 of Ocean Drilling Program Leg 115 form a transect from $13^{\circ} \mathrm{S}$ to $5^{\circ} \mathrm{N}$ in the equatorial region of the western Indian Ocean. Two major cycles of biogenic silica accumulation appear in the sedimentary record from middle Eocene to early Oligocene and again from middle Miocene to Holocene. Diatoms are rare and poorly preserved in the recovered biosiliceous sediments of Paleogene age, whereas radiolarians and siliceous sponge spicules are well developed in these sequences. Diatoms are absent from sediments of early Oligocene to late middle Miocene age. They reappear around $8 \mathrm{Ma}$ in the sites south of the equator. In contrast, well-developed middle Miocene diatom assemblages are present beginning at $13 \mathrm{Ma}$ at Site 714 north of the equator.

Two pulses of high diatom productivity appear in the Neogene sedimentary record. Productivity was high in the late Miocene-early Pliocene with the high-fertility belt located between $4^{\circ} \mathrm{S}$ and $7^{\circ} \mathrm{S}$. Diatom production ceased in the lateearly Pliocene but had a short-lived pulse again in the Pleistocene around $1 \mathrm{Ma}$. Between early Pliocene times and the present, the fertile belt of the western Indian Ocean shifted a few degrees north to the present-day location of the opalproducing sector confined to a belt between $3^{\circ} \mathrm{S}$ and $5^{\circ} \mathrm{S}$.
\end{abstract}

\section{INTRODUCTION}

Biostratigraphic and paleoecologic studies of diatoms in deepsea sediments from the equatorial Indian Ocean are remarkably few compared with the information available on diatoms in the equatorial Pacific and Atlantic oceans. A pioneering work of regional significance in the equatorial Indian Ocean was made by Kolbe (1957), who distinguished a number of geographic areas on the basis of diatom assemblages in surface sediments. Kozlova (1971) reported on the occurrence of diatoms in surface sediments of the northern Indian Ocean.

Before the inception of the Ocean Drilling Program (ODP), studies of low-latitude diatom floras in the Indian Ocean from extended deep-sea cores were limited to those of Schrader (1974), who reported on the late Miocene though Pleistocene sequence of Deep Sea Drilling Project (DSDP) Sites 213, 216, 236, and 238; Jousé and Kazarina (1974), who studied Pleistocene diatoms from Site 262 in the eastern Indian Ocean; and Kazarina (1982), who worked on upper Miocene-lower Pliocene diatom assemblages from DSDP Site 252. Recently, Schmitz (1987) used the biogenic opal content of some DSDP sites to backtrack these sites for plate motion.

Leg 115 was the first of a nine-leg program with the purpose of investigating the Indian Ocean. The objectives of the leg were to study the evolution of the Indian Ocean in a hotspot framework, and to decipher in detail changes in the Neogene paleoceanography in the equatorial western part of the ocean basin. This paper will present a diatom biostratigraphy of the sequences recovered during Leg 115 (Fig. 1 and Table 1) and to extract the paleoceanographic signals provided by the diatoms in the biosiliceous sediments.

\section{METHODS}

\section{Preparation}

All core-catcher samples recovered on Leg 115 were processed during the cruise in batches of 10-15 samples per batch.

\footnotetext{
${ }^{1}$ Duncan, R. A., Backman, J., Peterson, L. C., et al., 1990. Proc. ODP, Sci. Results, 115: College Station, TX (Ocean Drilling Program).

2 Geological Survey of Denmark, Thoravej 8, 2400 Copenhagen NV, Denmark.
}

Approximately 2-3 g of each sample were placed in a $250-\mathrm{ml}$ beaker and $25-\mathrm{ml}$ of $10 \%$ hydrochloric acid was added. The sample was gently heated until the liquid became light yellow. Treatment with $30 \%$ hydrogen peroxide was rarely required. The acidity of the sample was diluted by adding 200 -ml distilled water. The liquid was decanted after $1 \frac{1 / 2}{\mathrm{hr}}$, and the decanting process was repeated three times. Smear slides were prepared by transferring the suspended material with a disposable pipette to a $22-\times 40-\mathrm{mm}$ cover slip, which was dried and mounted with Hyrax on 22- $\times 75$-mm glass slides. Additional samples were prepared after the cruise. To save material, only a small amount of sample $(0.1 \mathrm{~g})$ was placed in a $50-\mathrm{ml}$ glass tube and subjected to the settling method described above.

\section{Procedures}

The microscope slides were examined with a Leitz Ortholux microscope and scanned at $500 \times$ to check for the presence of biostratigraphic marker species. These species were mainly selected from Barron (1985a, 1985c) and Fenner (1985). The criteria for distinguishing whole from broken diatoms followed Schrader and Gersonde (1978).

As in Baldauf (Shipboard Scientific Party, 1988a), species were recorded as abundant if two or more specimens were present in one field of view at $500 \times$; common if one specimen occurred in two fields of view; few if one specimen was observed in one horizontal traverse; and rare if less than one specimen was encountered per transverse. Special analyses of diatom populations were made by counting 300 specimens in a series of random transverses of individual samples.

Assessment of the total diatom abundance was qualitative. It was recorded as the coverage of diatom valves on the slide surface relative to other particles (in percent). The abundance of diatoms was listed as absent $(-)$, trace (TR, $<1 \%$ ), rare $(\mathrm{R},<5 \%)$, few $(\mathrm{F}, 5 \%-30 \%)$, common (C, 30\%-60\%), and abundant $(\mathrm{A},>60 \%)$. Diatom preservation was recorded as good $(G)$ when fine structures of the valves were preserved and weakly silicified forms were present in the assemblages; moderate $(\mathrm{M})$ when the assemblage showed moderate breakage and slight dissolution; and poor $(\mathrm{P})$ when more than $30 \%$ of all valves were broken and the assemblage was affected by partial dissolution. 


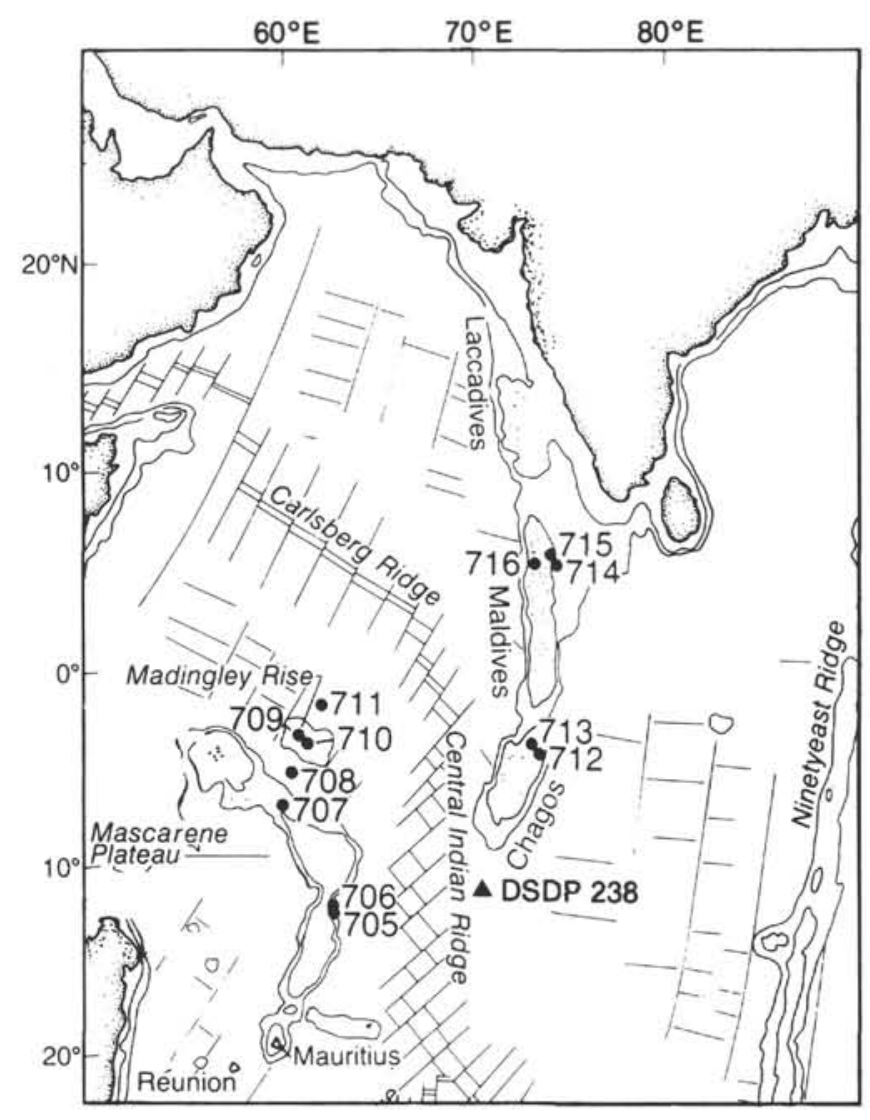

Figure 1. Location of Leg 115 sites, DSDP Site 238, and major ridge crests and fracture zones of the western Indian Ocean.

Table 1. Location and water depth of Leg 115 holes.

\begin{tabular}{|c|c|c|}
\hline Hole & $\begin{array}{c}\text { Position } \\
\text { (latitude, longitude) }\end{array}$ & $\begin{array}{c}\text { Water } \\
\text { depth } \\
\text { (m) }\end{array}$ \\
\hline $705 \mathrm{~A}$ & $13^{\circ} 10.00^{\prime} \mathrm{S}, 61^{\circ} 22.27^{\prime} \mathrm{E}$ & 2307.5 \\
\hline $706 \mathrm{~A}$ & $13^{\circ} 06.86^{\prime} \mathrm{S}, 61^{\circ} 22.27^{\prime} \mathrm{E}$ & 2506.5 \\
\hline $706 \mathrm{~B}$ & $13^{\circ} 06.86^{\prime} \mathrm{S}, 61^{\circ} 22.27^{\prime} \mathrm{E}$ & 2507.5 \\
\hline $706 \mathrm{C}$ & $13^{\circ} 06.86^{\prime} \mathrm{S}, 61^{\circ} 22.27^{\prime} \mathrm{E}$ & 2507.5 \\
\hline $707 \mathrm{~A}$ & $7^{\circ} 32.72^{\prime} \mathrm{S}, 59^{\circ} 01.01^{\prime} \mathrm{E}$ & 1541.4 \\
\hline $707 \mathrm{~B}$ & $7^{\circ} 32.72^{\prime} \mathrm{S}, 59^{\circ} 01.01^{\prime} \mathrm{E}$ & 1541.4 \\
\hline $707 \mathrm{C}$ & $7^{\circ} 32.73^{\prime} \mathrm{S}, 59^{\circ} 01.01^{\prime} \mathrm{E}$ & 1541.4 \\
\hline $708 \mathrm{~A}$ & $5^{\circ} 27.23^{\prime} \mathrm{S}, 59^{\circ} 56.63^{\prime} \mathrm{E}$ & 4096.5 \\
\hline $709 \mathrm{~A}$ & $3^{\circ} 54.72^{\prime} \mathrm{S}, 60^{\circ} 33.16^{\prime} \mathrm{E}$ & 3038.2 \\
\hline 709B & $3^{\circ} 54.72^{\prime} \mathrm{S}, 60^{\circ} 33.16^{\prime} \mathrm{E}$ & 3038.2 \\
\hline $709 \mathrm{C}$ & $3^{\circ} 54.72^{\prime} \mathrm{S}, 60^{\circ} 33.16^{\prime} \mathrm{E}$ & 3038.2 \\
\hline $710 \mathrm{~A}$ & $4^{\circ} 18.69^{\prime} \mathrm{S}, 60^{\circ} 48.76^{\prime} \mathrm{E}$ & 3812.0 \\
\hline 710B & $4^{\circ} 18.69^{\prime} \mathrm{S}, 60^{\circ} 48.76^{\prime} \mathrm{E}$ & 3810.5 \\
\hline $711 \mathrm{~A}$ & $2^{\circ} 44.46^{\prime} \mathrm{S}, 61^{\circ} 09.75^{\prime} \mathrm{E}$ & 4428.2 \\
\hline $711 \mathrm{~B}$ & $2^{\circ} 44.47^{\prime} \mathrm{S}, 61^{\circ} 09.78^{\prime} \mathrm{E}$ & 4429.7 \\
\hline $712 \mathrm{~A}$ & $4^{\circ} 12.99^{\prime} \mathrm{S}, 73^{\circ} 24.38^{\prime} \mathrm{E}$ & 2892.4 \\
\hline $713 \mathrm{~A}$ & $4^{\circ} 11.58^{\prime} \mathrm{S}, 73^{\circ} 23.65^{\prime} \mathrm{E}$ & 2909.5 \\
\hline $714 \mathrm{~A}$ & $5^{\circ} 03.69^{\prime} \mathrm{N}, 73^{\circ} 46.98^{\prime} \mathrm{E}$ & 2231.5 \\
\hline $714 \mathrm{~B}$ & $5^{\circ} 03.69^{\prime} \mathrm{N}, 73^{\circ} 46.98^{\prime} \mathrm{E}$ & 2231.5 \\
\hline $715 \mathrm{~A}$ & $5^{\circ} 04.89^{\prime} \mathrm{N}, 73^{\circ} 49.88^{\prime} \mathrm{E}$ & 2269.3 \\
\hline $716 \mathrm{~A}$ & $4^{\circ} 56.00^{\prime} \mathrm{N}, 73^{\circ} 17.01^{\prime} \mathrm{E}$ & 533.3 \\
\hline $716 \mathrm{~B}$ & $4^{\circ} 56.00^{\prime} \mathrm{N}, 73^{\circ} 17.01^{\prime} \mathrm{E}$ & 533.3 \\
\hline
\end{tabular}

\section{BIOSTRATIGRAPHY}

\section{Introduction}

Biostratigraphic studies based on diatoms have accelerated during the last $15 \mathrm{yr}$. Results from these studies have been com- piled by Barron $(1985 \mathrm{a}, 1985 \mathrm{c})$ into an excellent middle- to lowlatitude diatom zonation that covers the interval from the late Oligocene through Holocene time.

The pioneering work on late Cenozoic diatom stratigraphy by Burckle (1972) in the equatorial Pacific was correlated directly to the paleomagnetic stratigraphy. Since then, additional diatom levels have been tied to the magnetostratigraphic record (Burckle, 1977, 1978; Burckle and Opdyke, 1977; Burckle and Trainer, 1979; Burckle et al., 1982). Other low-latitude diatom studies in the Pacific, which has been a key area for diatom biostratigraphic work since the beginning of DSDP, include those by Bukry and Foster (1973), Schrader (1973), Barron (1980a, 1980b, 1981, 1983, 1985a, 1985b), Sancetta (1982, 1983), Barron et al. (1985a, 1985b), and Baldauf (1985). Schrader (1974) proposed a low-latitude diatom zonation for the late Miocene to Quaternary of the Indian Ocean (Fig. 2).

\section{Indian Ocean Zonations}

The diatom zonation used during Leg 115 is that compiled by Barron (1985a, 1985c) who introduced code numbers for the zones (Fig. 2 and Table 2). It consists of Burckle's (1972) late Miocene through Quaternary zonation; Barron's (1983) late Oligocene to middle Miocene zonation; and Fenner's (1984, 1985) Paleogene zonation.

The marine magnetic anomaly time scale of Berggren et al. $(1985 \mathrm{a}, 1985 \mathrm{~b})$ is used but this time scale does not incorporate a diatom zonation. As the paleomagnetic control on diatom events in the Leg 115 sequences is limited, magnetostratigraphically calibrated first and last occurrences of diatom species are based, therefore, on the information given in Barron (1985a, 1985c), Barron et al. (1985a, 1985b) and J. A. Barron (pers. comm., 1988). The species events and their assigned age estimates are listed in Table 2 . The majority of the younger events have a direct paleomagnetic control, whereas the ages of most of the older events are based on extrapolations. The correlation between the nannofossil zonation of Okada and Bukry (1980) and the diatom zonation of Barron (1985a, 1985c) is based on nannofossil ages given by Rio and Okada in Shipboard Scientific Party (1988b) and diatom ages given by J. A. Barron (pers. comm., 1988).

\section{Site Descriptions}

We drilled 12 sites (Sites 705 through 716) with a total number of 22 holes in the equatorial Indian Ocean on Leg 115 (Fig. 1 and Table 1). A special suite of sites (Sites 707 through 711) was drilled as a depth transect within a restricted geographic area. These sites should help special studies of the Neogene paleoceanography and carbonate budget of the equatorial Indian Ocean.

The general biostratigraphy of the recovered Leg 115 sediments is summarized in Figure 3. Most sites provide a well-developed Neogene sequence, although hiatuses or highly reduced sedimentation rates typify the sequences around the middle to late Miocene boundary. The oldest sediment recovered during Leg 115 is of Paleocene age (Fig. 3). Diatoms of Paleogene ages are described in more detail in Fenner and Mikkelsen (this volume).

\section{Site 705}

Site 705 , located on the eastern shoulder of the Mascarene Plateau, was planned to recover basement rocks for studies of the Cenozoic plate movements. Because of hole instabilities, only three cores of foraminifer sand were recovered from the 27.5-m cored interval of Hole 705A.

In the recovered sequence, which spans the Pleistocene and late Pliocene, only a few reworked diatoms of Miocene age are present in the Pliocene section. 


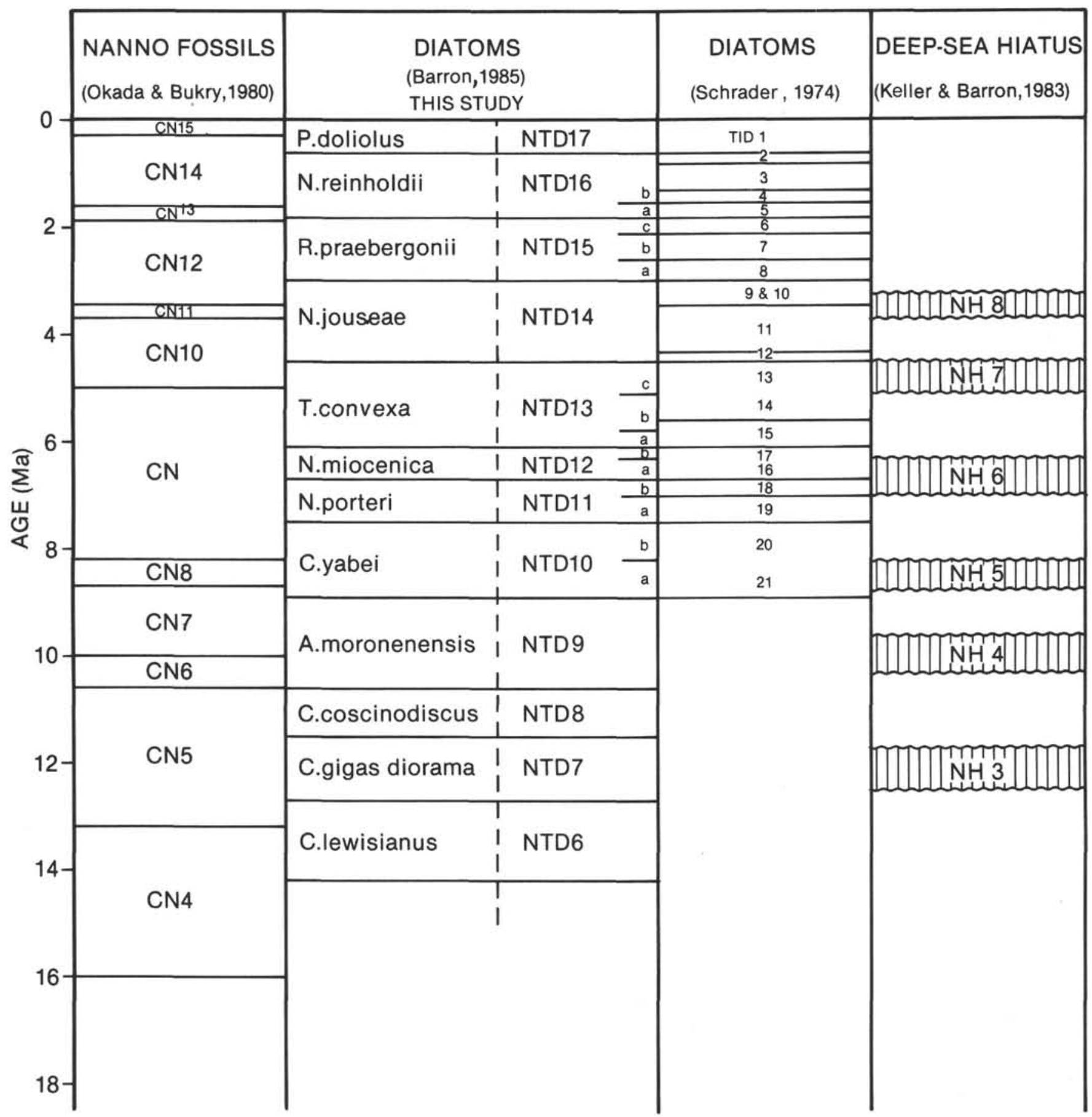

Figure 2. Comparison between the nannofossil zonation of Okada and Bukry (1980), the diatom zonation for the Indian Ocean of Schrader (1974), and the low-latitude diatom zonation of Barron (1985a). The deep-sea hiatuses from NH8 to NH4 of Keller and Barron (1983) are recognized in the diatom record of Leg 115.

\section{Site 706}

Three holes were drilled at a water depth of $2318 \mathrm{~m}$ at Site 706 on the Mascarene Plateau. Basement penetration was the main objective of this site. A Pleistocene sequence followed by a lower Oligocene section was met above the basalt. The Pleistocene corecatcher samples were barren of diatoms and only a few traces of diatom valves were found in the lower Oligocene samples.

\section{Site 707}

Three holes were drilled at a water depth of $1541 \mathrm{~m}$. The objective was to recover a continous Neogene sequence above the calcium carbonate compensation (CCD) depth. Hole 707A continued into sediments of late Eocene age. The oldest sequence recovered during Leg 115 contained sediments of Paleocene age in Hole 707C. 
Table 2. Species events defining diatom zonal boundaries and their assigned age estimates.

\begin{tabular}{|c|c|c|c|c|}
\hline $\begin{array}{l}\text { Age } \\
\text { (Ma) }\end{array}$ & Event & Species & Diatom zone & NTD \\
\hline 0.65 & ${ }^{\mathrm{a}} \mathbf{T}$ & ${ }^{\mathrm{b}}$ Nitzschia reinholdii & P. doliolus & 17 \\
\hline 0.8 & $\mathrm{~T}$ & Thalassiosira plicata & & \\
\hline 0.85 & $T$ & Nitzschia fossilis & & \\
\hline 0.94 & ${ }^{\mathrm{a}} \mathrm{T}$ & Rhizosolenia matuyamai & & $16 \mathrm{~b}$ \\
\hline 1.1 & ${ }^{\mathrm{a}} \mathrm{B}$ & Rhizosolenia matuyamai & N. reinholdii & \\
\hline 1.55 & ${ }^{\mathrm{a}} \mathbf{T}$ & ${ }^{\mathrm{b}}$ Rhizosolenia praebergonii var. robusta & & \\
\hline 1.6 & B & Azpeitia barronii & & \\
\hline 1.8 & ${ }^{\mathrm{a}} \mathrm{B}$ & ${ }^{b}$ Pseudoeunotia doliolus & & $16 \mathrm{a}$ \\
\hline 1.85 & ${ }^{\mathrm{a}} \mathrm{T}$ & Rhizosolenia praebergonii & & $15 \mathrm{c}$ \\
\hline 2.1 & ${ }^{\mathrm{a}} \mathrm{T}$ & ${ }^{\mathrm{b}}$ Thalassiosira convexa & & $\overline{15 b}$ \\
\hline 2.6 & ${ }^{\mathrm{a}} \mathrm{T}$ & Nitzschia jouseae & R. praebergonii & \\
\hline 3.0 & ${ }^{\mathrm{a}} \mathrm{B}$ & ${ }^{\mathrm{b}}$ Rhizosolenia praebergonii & & $15 \mathrm{a}$ \\
\hline 3.2 & $T$ & Actinocyclus ellipticus $\mathrm{f}$. lanceolata & & \\
\hline 3.6 & ${ }^{\mathrm{a}} \mathrm{B}$ & Thalassiosira convexa var. convexa & & \\
\hline 3.9 & ${ }^{\mathrm{a}} \mathrm{B}$ & Asteromphalus elegans & N. jouseae & 14 \\
\hline 4.3 & ${ }^{\mathrm{a}} \mathrm{T}$ & Nitzschia cylindrica & & \\
\hline 4.5 & ${ }^{\mathrm{a}} \mathrm{B}$ & ${ }^{\mathrm{b}}$ Nitzschia jouseae & & \\
\hline 5.1 & ${ }^{\mathrm{a}} \mathrm{B}$ & Thalassiosira oestrupii & & $13 \mathrm{c}$ \\
\hline 5.1 & ${ }^{\mathrm{a}} \mathrm{T}$ & ${ }^{\mathrm{b}}$ Thalassiosira miocenica & & \\
\hline 5.35 & ${ }^{\mathrm{a}} \mathrm{T}$ & Asterolampra acutiloba & & \\
\hline 5.55 & ${ }^{\mathrm{a}} \mathrm{T}$ & Nitzschia miocenica & & \\
\hline 5.65 & ${ }^{\mathrm{a}} \mathrm{T}$ & Nitzschia miocenica var. elongata & T. convexa & $13 \mathrm{~b}$ \\
\hline 5.8 & ${ }^{\mathrm{a}} \mathrm{T}$ & ${ }^{\mathrm{b}}$ Thalassiosira praeconvexa & & \\
\hline 6.0 & ${ }^{\mathrm{a}} \mathbf{T}$ & Rossiella praepaleacea & & \\
\hline 6.1 & ${ }^{\mathrm{a}} \mathrm{B}$ & Thalassiosira miocenica & & $13 \mathrm{a}$ \\
\hline 6.1 & ${ }^{a} B$ & ${ }^{\mathrm{b}}$ Thalassiosira convexa var. aspinosa & & . \\
\hline 6.3 & ${ }^{a} B$ & ${ }^{\mathrm{b}}$ Thalassiosira praeconvexa & & $12 \mathrm{~b}$ \\
\hline 6.7 & ${ }^{\mathrm{a}} \mathrm{T}$ & Nitzschia porteri & N. miocenica & \\
\hline 6.7 & ${ }^{\mathrm{a}} \mathrm{B}$ & ${ }^{\mathrm{b}}$ Nitzschia miocenica & & $12 \mathrm{a}$ \\
\hline 6.9 & ${ }^{\mathrm{a}} \mathrm{T}$ & Rossiella paleacea & & $11 \mathrm{~b}$ \\
\hline 7.0 & ${ }^{\mathrm{a}} \mathrm{T}$ & ${ }^{\mathrm{b}}$ Thalassiosira burckliana & & \\
\hline 7.3 & B & Nitzschia reinholdii & N. porteri & $11 \mathrm{a}$ \\
\hline 7.3 & $\mathrm{~T}$ & Actinocyclus ellipticus var. javanicus & & \\
\hline 7.4 & B & Nitzschia marina & & \\
\hline 7.5 & ${ }^{\mathrm{a}} \mathrm{T}$ & ${ }^{b}$ Thalassiosira yabei & & \\
\hline 7.6 & B & Nitzschia cylindrica & & \\
\hline 7.7 & ${ }^{\mathrm{a}} \mathbf{B}$ & Azpeitia nodulifer var. cyclopus & & \\
\hline 7.9 & $\mathrm{~T}$ & Thalassiosira yabei var. elliptica & & $10 \mathrm{~b}$ \\
\hline 7.9 & $\mathrm{~T}$ & Coscinodiscus loeblichii & & \\
\hline 8.05 & $\mathrm{~T}$ & Coscinodiscus temperei var. delicata & & \\
\hline 8.1 & B & Nitzschia fossilis & & \\
\hline 8.1 & B & Thalassiosira yabei var. elliptica & C. yabei & \\
\hline 8.2 & ${ }^{a_{B}}$ & ${ }^{\mathrm{b}}$ Thalassiosira burckliana & & \\
\hline 8.4 & B & Coscinodiscus loeblichii & & $\overline{10 a}$ \\
\hline 8.5 & ${ }^{\mathrm{a}} \mathrm{T}$ & Azpeitia vetustissimus var. javanica & & \\
\hline 8.75 & B & Azpeitia vetustissimus var. javanica & & \\
\hline 8.9 & ${ }^{\mathrm{a}} \mathrm{T}$ & ${ }^{b}$ Actinocyclus moronensis & & \\
\hline 9.9 & B & Actinocyclus ellipticus f. lanceolata & & \\
\hline 10.1 & ${ }^{\mathrm{a}} \mathrm{T}$ & Coscinodiscus tuberculatus & A. moronensis & 9 \\
\hline 10.4 & $\mathrm{~T}$ & Synedra jouseana & & \\
\hline 10.6 & ${ }^{\mathrm{a}} \mathrm{T}$ & ${ }^{\mathrm{b}}$ Craspedodiscus coscinodiscus & & \\
\hline 10.6 & B & Rossiella paleacea var. elongata & & \\
\hline 10.6 & ${ }^{\mathrm{a}} \mathbf{T}$ & Denticulopsis punctata & & \\
\hline 10.6 & B & Thalassionema robusta & & \\
\hline 10.7 & $\mathbf{T}$ & Coscinodiscus gigas var. diorama & & \\
\hline 10.8 & $\mathbf{T}$ & Actinocyclus ellipticus var. spiralis & C. coscinodiscus & 8 \\
\hline 11.1 & ${ }^{\mathrm{a} B}$ & Hemidiscus cuneiformis & & \\
\hline 11.45 & B & Rossiella praepaleacea & & \\
\hline 11.5 & ${ }^{\mathrm{a}} \mathbf{B}$ & ${ }^{\mathrm{b}}$ Coscinodiscus temperei var. delicata $(=T$. brunii) & & \\
\hline 11.5 & $\mathbf{T}$ & Actinocyclus ingens & & \\
\hline 11.7 & B & Nitzschia porteri & & \\
\hline 12.2 & $\mathrm{~T}$ & Denticulopsis nicobarica & & \\
\hline 12.4 & $\mathrm{~T}$ & Annellus californicus & C. gigas diorama & 7 \\
\hline 12.5 & $\mathrm{~T}$ & Azpeitia salisburyanus & & \\
\hline 12.6 & B & Coscinodiscus gigas var. diorama & & \\
\hline
\end{tabular}

The recovered Pleistocene and upper Pliocene sediments are barren of diatoms and only radiolarians and rare siliceous sponge spicules are present. Because radiolarians and especially diatoms are more susceptible to dissolution than siliceous sponge spicules, the youngest section of Site 707 apparently reflects a dissolution profile. In the early Pliocene-late Miocene diatom zones Nitzschia jouseae (NTD14), Thalassiosira convexa (NTD13), and Nitzschia miocenica (NTD12), the diatom abundance and preservation fluctuate. The assemblage of the early Pliocene $N$. jouseae (NTD14) Zone is characterized by a steady background 
Table 2 (continued).

\begin{tabular}{|c|c|c|c|c|}
\hline $\begin{array}{l}\text { Age } \\
(\mathrm{Ma})\end{array}$ & Event & Species & Diatom zone & NTD \\
\hline 12.7 & ${ }^{\mathrm{a}} \mathrm{T}$ & ${ }^{\mathrm{b}}$ Coscinodiscus lewisianus & & \\
\hline 12.9 & $\mathbf{T}$ & Cestodiscus pulchellus & & \\
\hline 13.0 & B & Denticulopsis punctata & & \\
\hline 13.25 & ${ }^{\mathrm{a}} \mathrm{T}$ & Thalassiosira tappanae & & \\
\hline 13.3 & B & Azpeitia nodulifer & & \\
\hline 13.4 & B & Triceratium cinnamomeum & & \\
\hline 13.4 & B & Thalassiosira grunowii & C. lewisianus & 6 \\
\hline 13.6 & ${ }^{\mathrm{a}} \mathrm{B}$ & Denticulopsis hustedtii main & & \\
\hline 13.9 & ${ }^{\mathrm{a} B}$ & Coscindiscus tuberculatus & & \\
\hline 13.9 & $\mathrm{~T}$ & Cestodiscus pulchellus var. maculatus & & \\
\hline 14.2 & B & Actinocyclus ellipticus var. spiralis & & \\
\hline
\end{tabular}

Notes: Ages are derived from Barron (1985a, 1985b), Barron et al. (1985a, 1985b), and J. A. Barron (pers. comm., 1988).

a Species events $(B=$ bottom of first appearance datum and $T=$ top of last appearance datum)

with a direct tie to the paleomagnetic time scale.

b Diatom species defining zonal boundaries.

of redeposited benthic diatoms, which are common especially in the lower part of the zone.

Benthic diatoms are present in the middle and lower part of the Thalassiosira convexa Zone (NTD13). They are especially conspicuous in Subzone NTD13b. Benthic diatoms are also present in the late Miocene $N$. miocenica (NTD12) Zone where reworked Miocene species of Actinocyclus are also found. Only traces of diatoms are present in Neogene sediments older than the Zone NTD12. The early Oligocene and middle to late Eocene biosiliceous sediments contain rare and poorly preserved assemblages of large and heavily silicified shallow-water diatom species.

\section{Site 708}

One hole was drilled at a water depth of $4109 \mathrm{~m}$ at the Seychelles Bank. It recovered a Pleistocene through Oligocene sequence and is characterized by the presence of numerous turbidites.

Diatoms are common and well preserved in the Pleistocene Pseudoeunotia doliolus Zone (NTD17) and the youngest subzone of Nitzschia reinholdii (NTD16b). Reworked middle Miocene and early late Miocene diatoms are present in the late Pliocene and late Miocene of the Rhizosolenia praebergonii (NTD15) and $T$. convexa (NTD13) zones, where benthic diatoms are also fairly common. The middle to late Miocene Coscinodiscus yabei Zone (NTD10) contains very rare and poorly preserved diatoms. The middle through early Miocene is barren of diatoms. Diatoms of early and late Oligocene age are present in low abundances and have a scattered occurrence in the biosiliceous sediments. These sparse assemblages contain shallow-water species as well as fully planktonic diatoms.

\section{Site 709}

Three holes were drilled at a water depth of $3049 \mathrm{~m}$ on the Madingley Rise. They recovered a fairly homogenous sedimentary sequence of nannofossil ooze that spans the Pleistocene through middle Eocene.

Diatoms are common and well preserved only in the Pleistocene sequence of the $P$. doliolus Zone (NTD17) and an expanded section covering the younger subzone of the $N$. reinholdii Zone (NTD16). Diatoms are remarkably rare and poorly preserved in the underlying Neogene sediments, which are affected by silica dissolution.

Diatoms are especially rare and poorly preserved in lower Subzone NTD16a of the $N$. reinholdii Zone and youngest Subzone NTD15c of the underlying $R$. praebergonii Zone (NTD15).
A restricted interval in the middle of the $N$. jouseae Zone (NTD14) is barren of diatoms. Reworked diatoms of late Oligocene age are present in the lowermost part of Zone NTD14 and in youngest Subzone NTD13c of the $T$. convexa Zone (NTD13). The oldest Neogene diatoms in Site 709 belong to the late Miocene $N$. miocenica Zone (NTD12). Diatoms are absent in the early late Miocene to late Oligocene sequence.

In the lower Oligocene sediments of Site 709, sparse assemblages with fairly diverse diatoms are indicative of open-ocean conditions.

\section{Site 710}

Two holes were drilled at Site 710 in a water depth of $3810 \mathrm{~m}$ on the central part of the Madingley Rise, and recovered sediments of Pleistocene through early Oligocene ages. Diatoms are fairly common and well preserved throughout the late Neogene, and all zones down to and including the late Miocene $N$. miocenica Zone (NTD12) are recognized. Diatoms were not found in the early late Miocene to late Oligocene sediments, and only a few valve fragments were observed in the early Oligocene.

\section{Site 711}

Two holes of Site 711 were drilled at a water depth of $4424 \mathrm{~m}$ at the northern edge of the Madingley Rise, where a Pleistocene through middle Eocene section was recovered.

The Neogene diatom record of Site 711 is poor. Only poorly preserved and rare diatoms of late Pleistocene age (Zone NTD17 and Subzone NTD16b) were encountered. This might be a result of the low sedimentation rate, which allows the siliceous valves a longer residence time in the silica undersaturated environment of the sediment-water interface than in more shallow sites with higher sedimentation rates.

The Paleogene record of Site 711 furnishes two diatom-bearing intervals. Poor assemblages of early Oligocene age are dominated by shallow-water species, whereas the sparse diatom assemblages of middle to late Eocene age are dominated by open-ocean forms.

\section{Site 712}

Site 712 was drilled at a water depth of $2503 \mathrm{~m}$ on the northern margin of the Chagos Bank. The basement objective was not reached because of hole instabilities, but a Pliocene to upper Miocene sequence was recovered above an upper Oligocene and middle Eocene ash-bearing nannofossil ooze.

Diatoms are rare and poorly preserved in the youngest Pliocene sediments. Well-preserved diatom assemblages of early Pli- 


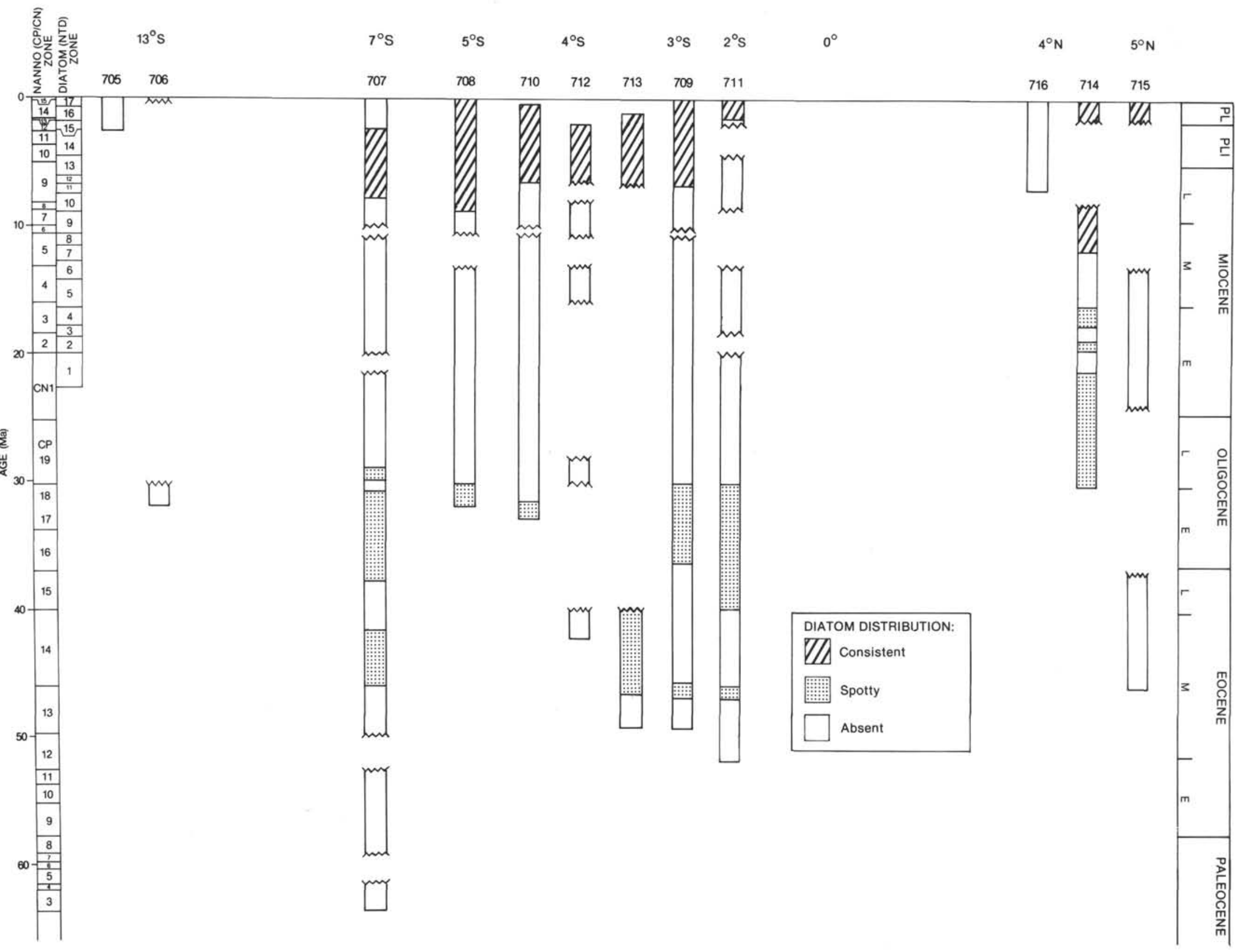

Figure 3. General biostratigraphy of sediment sections cored at Sites 705-716. The sites are plotted according to latitude and with an indication of the stratigraphic occurrences of diatoms. The diatom zonation is from Barron (1985a, 1985c) and the nannofossil zonation from Okada and Bukry (1980). Nannofossil data are from Okada and Rio (Shipboard Scientific Party, 1988b). 
ocene age were referred to the $N$. jouseae Zone (NTD14) and the $T$. convexa Zone (NTD13). Benthic diatoms are present in Subzone NTD13a.

\section{Site 713}

A basement objective was reached at Site 713 after penetration of an incomplete Pleistocene through middle Eocene sequence. The site was drilled as one hole at a water depth of 2911 $\mathrm{m}$ on the northern margin of the Chagos Bank.

Diatoms are rare and poorly preserved in the Pleistocene and upper Pliocene section, but they are fairly common and well preserved in the early Pliocene $N$. jouseae (NTD14) and $T$. convexa (NTD13) zones. Benthic diatoms are present throughout these zones. Only well-preserved assemblages of late Miocene age belonging to the $N$. miocenica Zone (NTD12) were observed at Site 713.

Diatoms have a rare occurrence in the middle Eocene sediments, where neritic diatom species dominate the sparse assemblages.

\section{Site 714}

Two holes were drilled at Site 714 on the Maldives Ridge at $2042 \mathrm{~m}$ water depth. The recovered sequences span the Pleistocene through upper Oligocene with a conspicuous hiatus covering the early Pleistocene through late Miocene.

Diatoms are absent or very rare and poorly preserved in the Pleistocene section of Site 714. Diatoms are fairly common and well preserved in the late Miocene $C$. yabei Subzone (NTD10a) and in the expanded Actinocyclus moronensis Zone (NTD9). These late Miocene assemblages are, in certain intervals, dominated by Thalassionema sp. In the lower part of late Miocene Zone NTD9, an incursion of the cold-water diatom Coscinodiscus marginatus is noted.

The diverse diatom assemblages continue downsection into the upper part of the middle Miocene $C$. coscinodiscus Zone (NTD8). Diatoms are rare and poorly preserved in the lower part of this zone as well as in the underlying Coscinodiscus gigas diorama Zone (NTD7). In the entire Miocene section heavily silicified benthic diatoms as well as siliceous sponge spicules are fairly common.

Diatoms are rare in sediments of late Oligocene age.

\section{Site 715}

One hole was drilled at Site 715 at a water depth of $2273 \mathrm{~m}$ on the eastern margin of the Maldives Ridge. The main objective was to penetrate the basement underlying the carbonate bank deposits, which form the Maldives Island chain.

A sedimentary section of Pleistocene through Eocene age was recovered with two conspicuous hiatuses covering the Oligocene and late Miocene to Pliocene.

Diatoms are almost absent in thick Pleistocene sequence except for two intervals at 1.0 and $21.8 \mathrm{mbsf}$. Siliceous sponge spicules and radiolarians are present throughout the Pleistocene sequence. Siliceous skeletons of late middle and early Miocene ages are not present. Biogenic silica is also absent in the reefal limestone of Eocene age.

\section{Site 716}

Two holes of Site 716 were located at a water depth of $544 \mathrm{~m}$ in the center of the Maldives Ridge. The recovered Pliocene through Holocene section was totally barren of any types of siliceous skeletons except for a few traces of radiolarian fragments in Sample 115-716A-1H-CC. In the upper Miocene sequence, opaline silica is present as heavily silicified sponge spicules.

\section{Biostratigraphy and Paleomagnetics}

\section{Biostratigraphy}

The Paleogene diatom biostratigraphy of siliceous sediments recovered during Leg 115 is summarized in Figure 4. Diatoms of Paleogene age have a very sporadic occurrence, and they are generally of early Oligocene and middle to late Eocene ages (Fenner and Mikkelsen, this volume). The early Oligocene assemblages are dominated by shallow-water diatoms, whereas the sparse middle to late Eocene diatoms are mainly represented by open-marine species. The Neogene diatom biostratigraphy of the recovered sequences is summarized in Figure 5. Diatoms have in general a fairly consistent occurrence in the Pleistocene to late Miocene interval of most recovered sequences although they are rare or absent in certain intervals. They are absent in all middle and lower Miocene sections, except for a few traces of diatom valves in the early Miocene of Site 714.

The late Pleistocene $P$. doliolus Zone (NTD17) is well represented in the sites where diatoms are preserved. The diversity of the well preserved assemblages is high and the preservation is generally good. The assemblages found in the studied material and those reported from the Indian Ocean by Schrader (1974), Jousé and Kazarina (1974), and Kazarina (1982) are very similar to the tropical Pacific assemblages of Barron (1980a, 1985a). The youngest subzone (NTD16b) of the early Pleistocene $N$. reinholdii Zone (NTD16) is also represented by well-developed assemblages in most sites. Subzone NTD16a was observed only in two sites (709 and 710), where diatoms were generally rare and poorly preserved. The youngest subzone (NTD15c) of the late Pliocene $R$. praebergonii Zone (NTD15) is also poorly represented in the studied material. Diatoms of this age are rare and in a poor state of preservation. The two older subzones were represented by better preserved and more abundant diatoms.

Diatoms are common and well preserved in the early Pliocene $N$. jouseae Zone (NTD14), except for a short interval around 3.4-3.6 Ma in the middle of the zone. The youngest subzone (NTD13c) of the late Miocene $T$. convexa Zone (NTD13) is generally poorly represented, whereas the two older subzones are characterized by well-developed diatom assemblages. The oldest consistently occurring diatom zone in the recovered sites is the youngest subzone of the late Miocene $N$. miocenica Zone (NTD12). Diatoms in the older Subzone NTD12a are generally rare and poorly preserved. Diatoms occur sporadically below this interval in all sites except for Site 714 north of the equator. Some poorly preserved assemblages in Sites 707 and 710 have a questionable affinity to the late Miocene Nitzschia porteri Zone (NTD11).

Sediments corresponding in age to the early late Miocene $C$. yabei Zone (NTD10) are present in most of the drilled sequences of Leg 115 (Fig. 3). However, rare and poorly preserved diatoms representing this zone are present only in the slumped sequences of Site 708 at $5^{\circ} \mathrm{S}$ and in Site 714 at $4^{\circ} \mathrm{N}$. The first upsection occurrence of diatoms in DSDP Site 238 is in Zone TID21 of Schrader (1974), which corresponds to the late Miocene Zone NTD10 (Fig. 2).

Site 714 , which has a present-day location north of the equator, is the only sequence of Leg 115 where a number of middle Miocene diatom zones are present. The A. moronensis Zone (NTD9) is well developed in Site 714 except for a short interval in the middle of the zone. The diverse diatom assemblages are dominated by pennate diatoms of the genus Thalassionema. In the lower part of the zone a short pulse of the cold-water species Coscinodiscus marginatus is present. In the equatorial Pacific the middle Miocene NTD9 Zone shows a remarkable increase in 


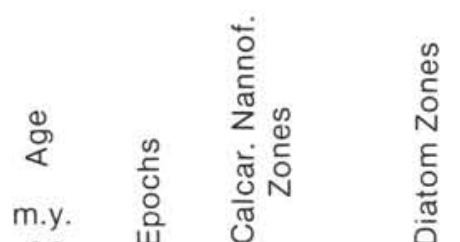

$22-1+1$

\begin{tabular}{|l|l|} 
Mioc. & $\mathrm{CN} 1$ \\
\cline { 1 - 1 } & $\mathrm{b}$
\end{tabular}

ODP ODP $\quad$ ODP

$\begin{array}{lllll} & & & \\ \text { ODP } & \text { DSDP } & \text { ODP } & \text { ODP } & \text { ODP }\end{array}$

DSDP

$714 \mathrm{~A}$
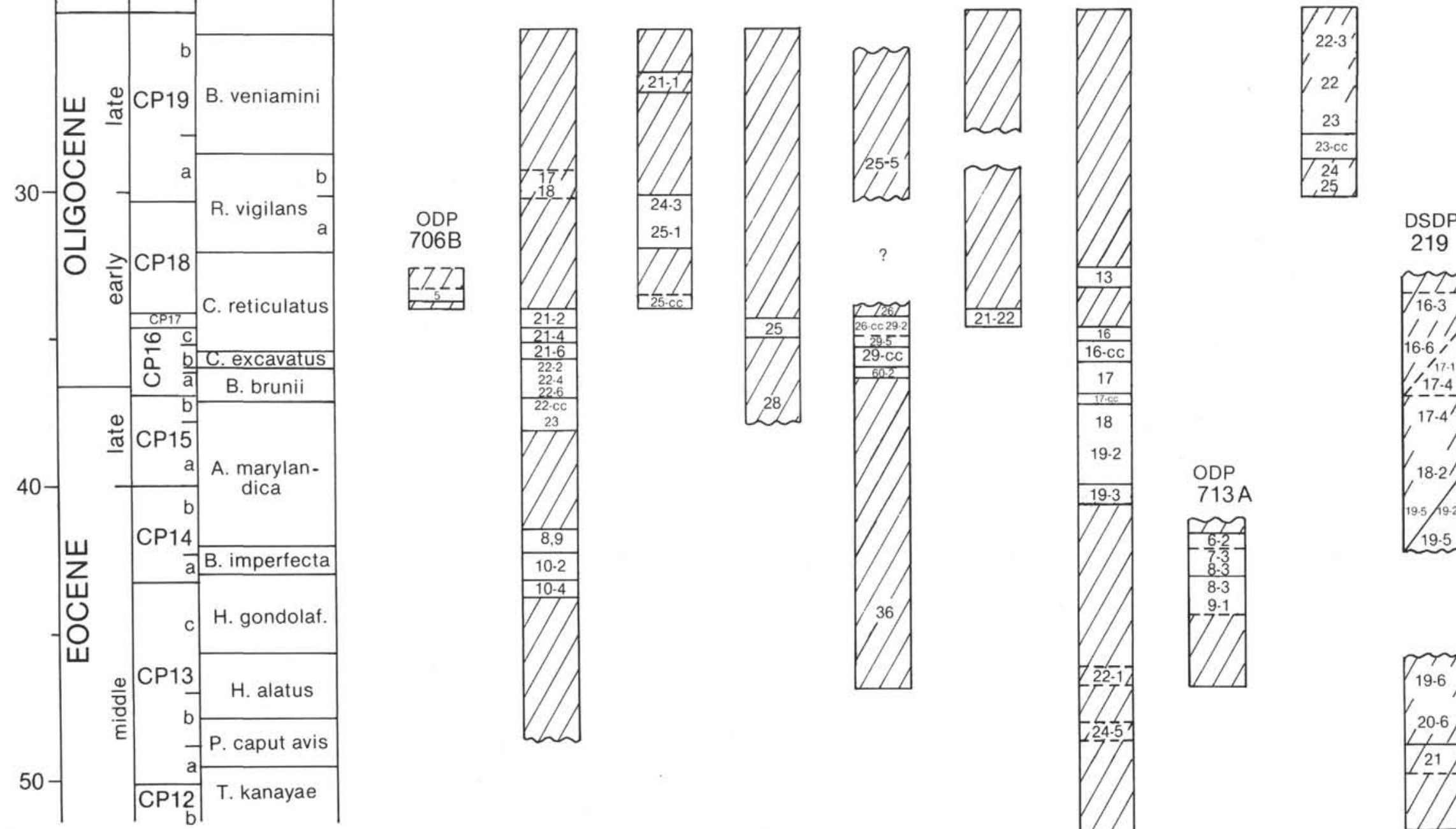

219

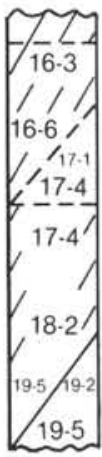

Figure 4. Summary of Paleogene diatom biostratigraphy of Leg 115 holes and DSDP Holes 219 and 236. For detailed information, see Fenner and Mikkelsen (this volume). 
cold-water diatoms, especially Denticulopsis hustedtii, which reaches a relative abundance of $50 \%$ to $60 \%$ around $10-9.3 \mathrm{Ma}$ (Barron, 1985b). This species is hardly recognized in sediments of similar ages in the low-latitude Indian Ocean, and except for C. marginatus, this also applies to other cold-water diatoms. Diatom assemblages of the middle Miocene $C$. coscinodiscus Zone (NTD8) are well developed in the upper part of the zone but become sparse downsection. This decrease in abundance continues into the underlying $C$. gigas diorama Zone (NTD7), where the oldest reliable record of Neogene diatoms was recognized in the western part of the equatorial Indian Ocean. Traces of diatom valves have been found in a few early Miocene samples of Site 714. This interval corresponds to nannofossil Zones CN1-CN3.

\section{Paleomagnetic Correlations}

A coherent paleomagnetic record of the drilled sequences was obtained only for Site 710 due to technical problems (Schneider, in Shipboard Scientific Party, 1988b). A correlation of biostratigraphic events to the magnetostratigraphy of the late Miocene to Quaternary section of Holes $710 \mathrm{~A}$ and $710 \mathrm{~B}$ is shown in Figure 6. The recovered sequence of Holes $710 \mathrm{~A}$ and $710 \mathrm{~B}$ is partly incomplete as a result of nonrecovery and drilling disturbances.

\section{Pseudoeunotia doliolus}

The first occurrence (FO) of Pseudoeunotia doliolus is just below the Olduvai Event at an age of $1.8 \mathrm{Ma}$. This age conforms with ages given by various authors (Burckle and Trainer, 1979; Barron, 1985a; Sancetta, 1983). P. doliolus has a peak abundance around $0.8 \mathrm{Ma}$. It is rare in Subzone NTD16b prior to this period in which the silicoflagellate Mesocena quandrangula is common.

\section{Nitzschia reinholdii}

The last occurrence (LO) of Nitzschia reinholdii defines the boundary between Pleistocene Zones NTD16 and NTD17. The extinction of $N$. reinholdii is difficult to determine in the equatorial Indian Ocean because the species has a rather sporadic occurrence close to its level of disappearance. The extinction event falls within the uppermost part of the Matuyama Chron in Site 710. Schrader (1974) placed this event in the middle part of the Brunhes Chron in Site 238 of the Indian Ocean.

In the mid- and high-latitude North Atlantic Ocean, the LO of $N$. reinholdii corresponds to the middle Brunhes paleomagnetic Chron (Baldauf, 1986a). In the Pacific Ocean, Sancetta (1982) found the LO of $N$. reinholdii just below the Jaramillo Event, whereas Barron (1985a) found its extinction within the lower part of the Brunhes Chron.

\section{Nitzschia fossilis}

The LO of $N$. fossilis is found within the upper part of the Matuyama Chron in Site 710, and it coincides with the LO of the silicoflagellate Mesocena quadrangula. In Site 709, where diatom preservation is poor, the LO of $N$. fossilis is found below the $M$. quadrangula extinction.

In the North Atlantic, the $\mathrm{LO}$ of $N$. fossilis is correlated with the early Brunhes paleomagnetic Chron (Baldauf, 1986a). This event is isochronous between high and middle latitudes of the North Atlantic but diachronous between the North Atlantic and Pacific oceans. Thus, Barron (1980a) referred the LO of N. fossilis in the central Pacific to an interval above the top of the Jaramillo Subchron in the Matuyama Chron, and he pointed out that it was equivalent in time with the $\mathrm{LO}$ of $M$. quadranqula.

The FO of $N$. fossilis in the Indian Ocean is significantly younger than in the Pacific Ocean. It appears in the late Miocene Zone NTD10 at $8.1 \mathrm{Ma}$ in the Pacific Ocean, whereas the FO in the western Indian Ocean is in the early Pliocene. In the paleomagnetic calibrated Hole 710A, N. fossilis first appears in Zone NTD13 at an age of 6.1 Ma. At DSDP Site 238, the FO of $N$. fossilis is given in Zone TID12 by Schrader (1974), which corresponds to the base of Zone NTD14.

\section{Nitzschia jouseae}

The LO of Nitzschia jouseae is easily recognized in most of the sites. In the paleomagnetically dated Hole $710 \mathrm{~A}$, the extinction of $N$. jouseae occurs within the Gauss Chron at an extrapolated age of $2.6 \mathrm{Ma}$. This is similar to the data given for North Atlantic by Baldauf (1986a) and Burckle and Trainer (1979) for the Pacific Ocean.

The first upsection occurrence of $N$. jouseae is recorded in Hole 710B within the Gilbert Event at an extrapolated age of 4.6 Ma. This event slightly predates an age of 4.5 Ma given in Barron (1985a) for the equatorial Pacific Ocean. Müller and Schrader (1989) also note that $N$. jouseae appears slightly earlier in the Mediterranean area than in the Pacific Ocean. Within the rather short range of $3 \mathrm{~m} . \mathrm{y}$. from appearance to extinction, $N$. jouseae undergoes significant morphological changes from a fairly long and slender morphotype to a short and broad type near its extinction. Nitzschia jouseae occurs in highest relative abundance in the middle of its range.

\section{Thalassiosira convexa}

The LO of T. convexa and its varieties is recognized in Hole $710 \mathrm{~A}$. It correlates to the upper part of the Gauss Chron and an age of $2.5 \mathrm{Ma}$.

The FO of $T$. convexa var. aspinosa is well defined in the Indian Ocean. It appears in Subzone NTD13a at an age of approximately 6.1 Ma, which is synchronous with the Pacific Ocean event given by Barron (1985a). This event is found to slightly predate the $T$. miocenica FO in Hole $710 \mathrm{~A}$. Burckle (1972) noted that the FO of $T$. miocenica occurred stratigraphically below the first appearance of $T$. convexa, whereas Baldauf (1984) recognized these two events as being synchronous.

Thalassiosira convexa and its varieties do not have a continous stratigraphic occurrence in the western part of the equatorial Indian Ocean. It is common in Subzones NTD13a and NTD13b, very rare and periodically absent in NTD13c and the lower part of NTD14, and again common to abundant in the middle part of Zone NTD14. Baldauf (1985) described a similar pattern for the eastern equatorial Pacific. The event of common T. convexa aspinosa in Zone NTD14 is, therefore, a useful stratigraphic datum, as pointed out by Baldauf (1985). This datum may be assigned an age of approximately $3.3 \mathrm{Ma}$ in the tropical Indian Ocean.

\section{Thalassiosira oestrupii}

The FO of Thalassiosira oestrupii has an extrapolated age of 5.3 Ma in Hole 710B. In the Pacific Ocean, this event is given an age of $5.1 \mathrm{Ma}$ (Barron, 1985a). The FO of T. oestrupii in the Indian Ocean is rather subtle because the first morphotypes to appear are rather unlike the characteristic forms that are present in high abundances in the Pleistocene assemblages. The increase in the abundance of $T$. oestrupii takes place around $1.7 \mathrm{Ma}$. A similar increase occurs in the Pacific Ocean between 1.8 and 1.9 Ma (Barron, 1985b).

\section{Mesocena quadrangula}

Silicoflagellates of the genus Mesocena are common in a restricted interval of all recovered early Pleistocene sections. These silicoflagellates have a worldwide distribution and a welldefined Pleistocene stratigraphic range, and are also easily recognized. Thus, they form useful stratigraphic markers.

The silicoflagellate genus Mesocena Ehrenberg, 1843, consists of a single basal ring without any central structure but with a varying number of spines. These features are used to distin- 


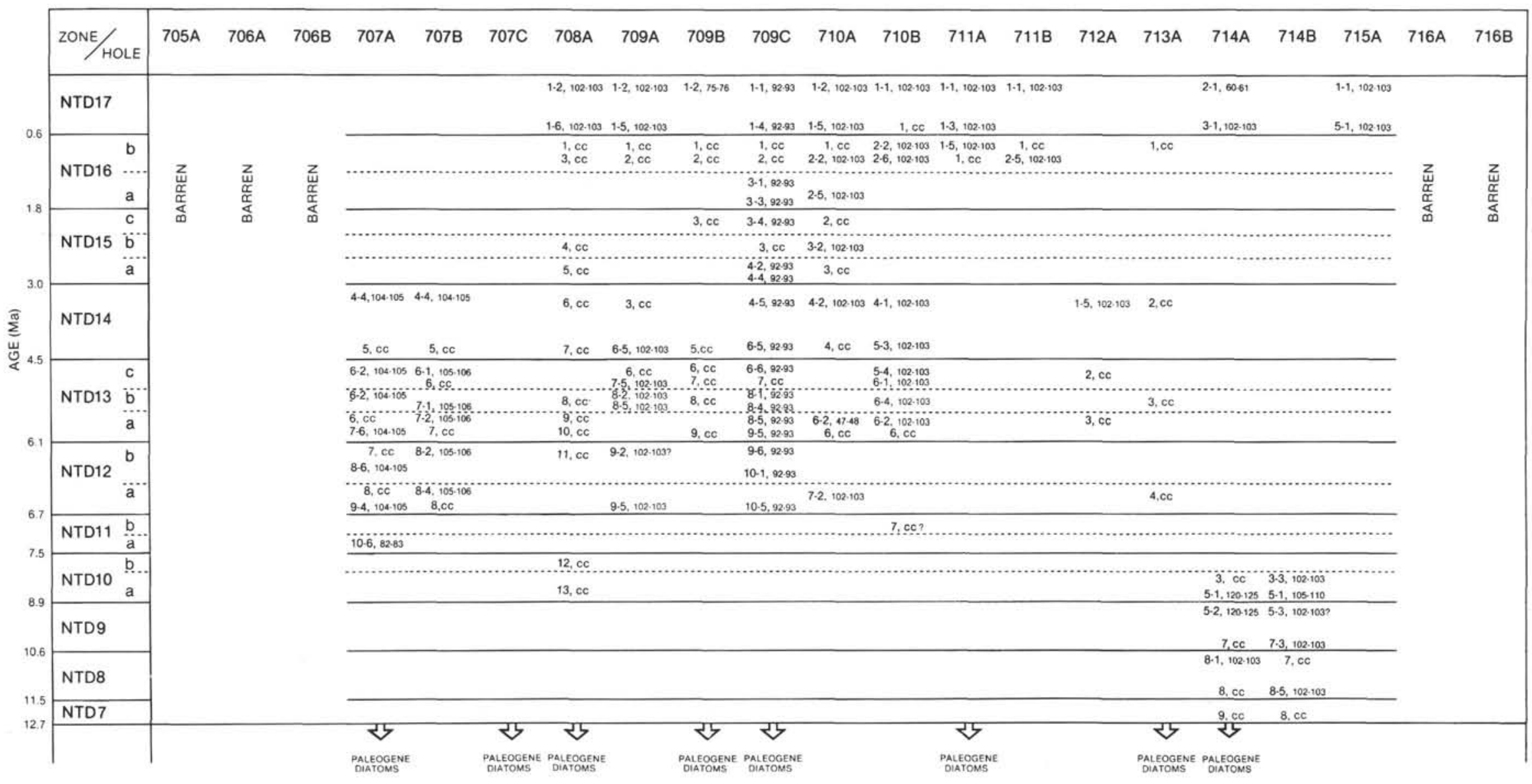

Figure 5. Neogene diatom biostratigraphy of Leg 115 sediments based on the zonation of Barron (1985a, 1985c). Ages of zonal boundaries are after J. A. Barron (pers. comm., 1988). The Paleogene diatom biostratigraphy is summarized in Figure 4. 


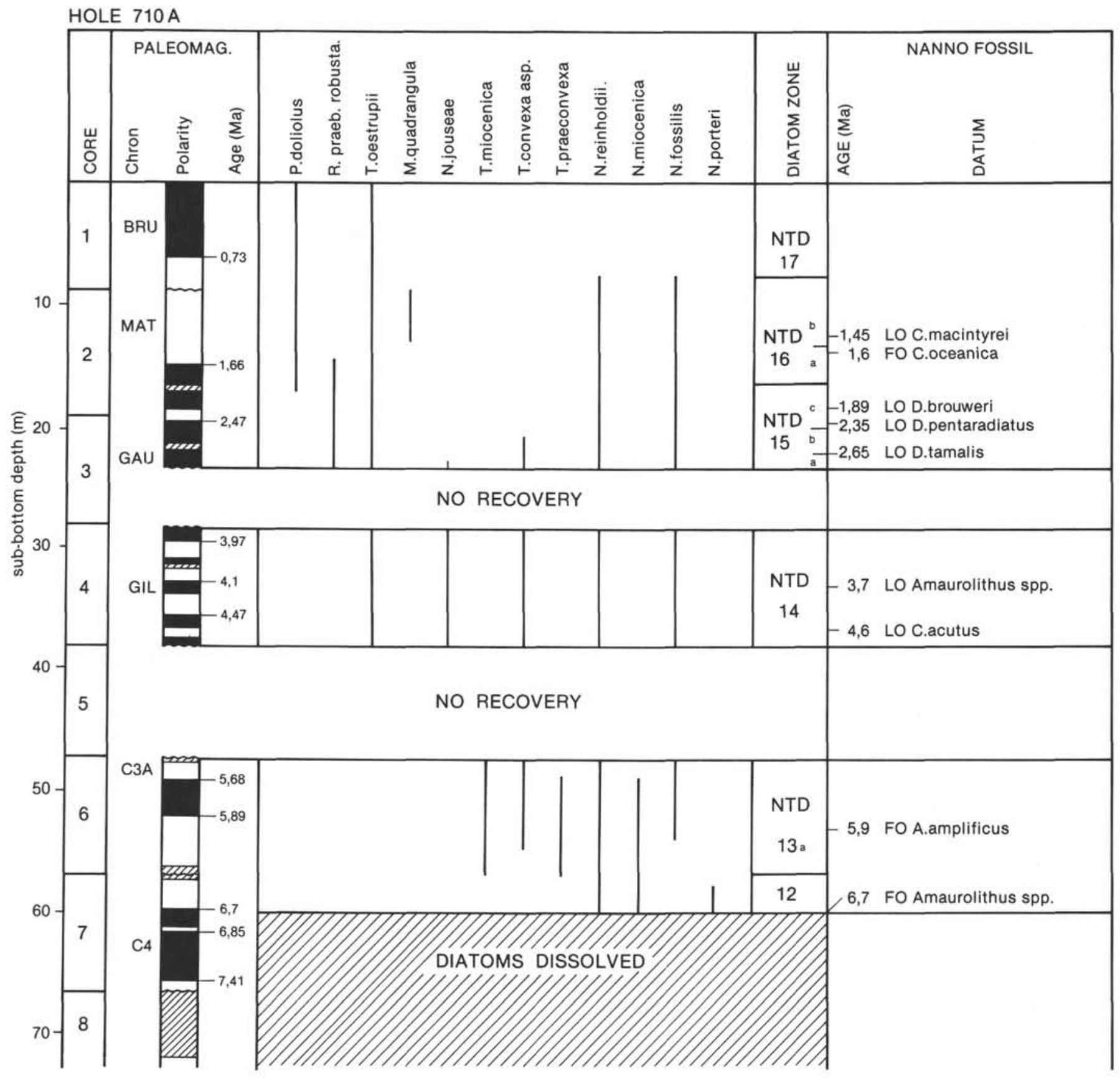

Figure 6. Correlation of biostratigraphic diatom events to the magnetic polarity interpretation of Holes 710A (Fig. 6A) and 710B (Fig. 6B) (magnetic data from Schneider, in Shipboard Scientific Party, 1988b). Black indicates zones of normal polarity, and white, zones of reversed polarity. Diagonal lines indicate disturbed zones of inconsistent magnetics, and wavy lines, core breaks. Episodes of sediment redeposition, which is apparent in nannofossil Zone CN9 (Okada and Rio in Shipboard Scientific Party, 1988b), may affect diatom ranges in Zones NTD11-NTD13. Nannofossil events are from Okada (H. Okada, pers. comm., 1988) and Rio (D. Rio, pers. comm., 1988).

guish a number of species within the genus. In the Indian Ocean material, two species are the dominant constituent of the late Neogene silicoflagellate assemblages: $M$. quadrangula, which has a more or less quadrangular form with four conical spines; and Mesocena elliptica, which is more elliptical in outline with four shorter spines. Transition forms between the two species often co-occur in the studied sections. All specimens of a more or less rhombic to quadrate outline are therefore referred to as Mesocena quadrangula. Bukry and Foster (1973) and Bukry (1985) point out that these quadrate Mesocena forms are coolwater indicators.
Specimens of quadrate Mesocena appear in the early Miocene, but they are common only in a very restricted interval of early Pleistocene age (Bukry, 1985). The common occurrence of Mesocena was originally noted by Hays et al. (1969) in tropical Pacific sediments. Later Martini (1971) established a late Pliocene to Holocene $M$. quadrangula Zone on the basis of the entire range of the name-giving species. Bukry and Foster (1973), who considered $M$. quadrangula as a junior synonym of $M$. elliptica, amended the zone to include only the interval where quadrate Mesocena were common to abundant and where the lower boundary was defined by the first post-Miocene common 


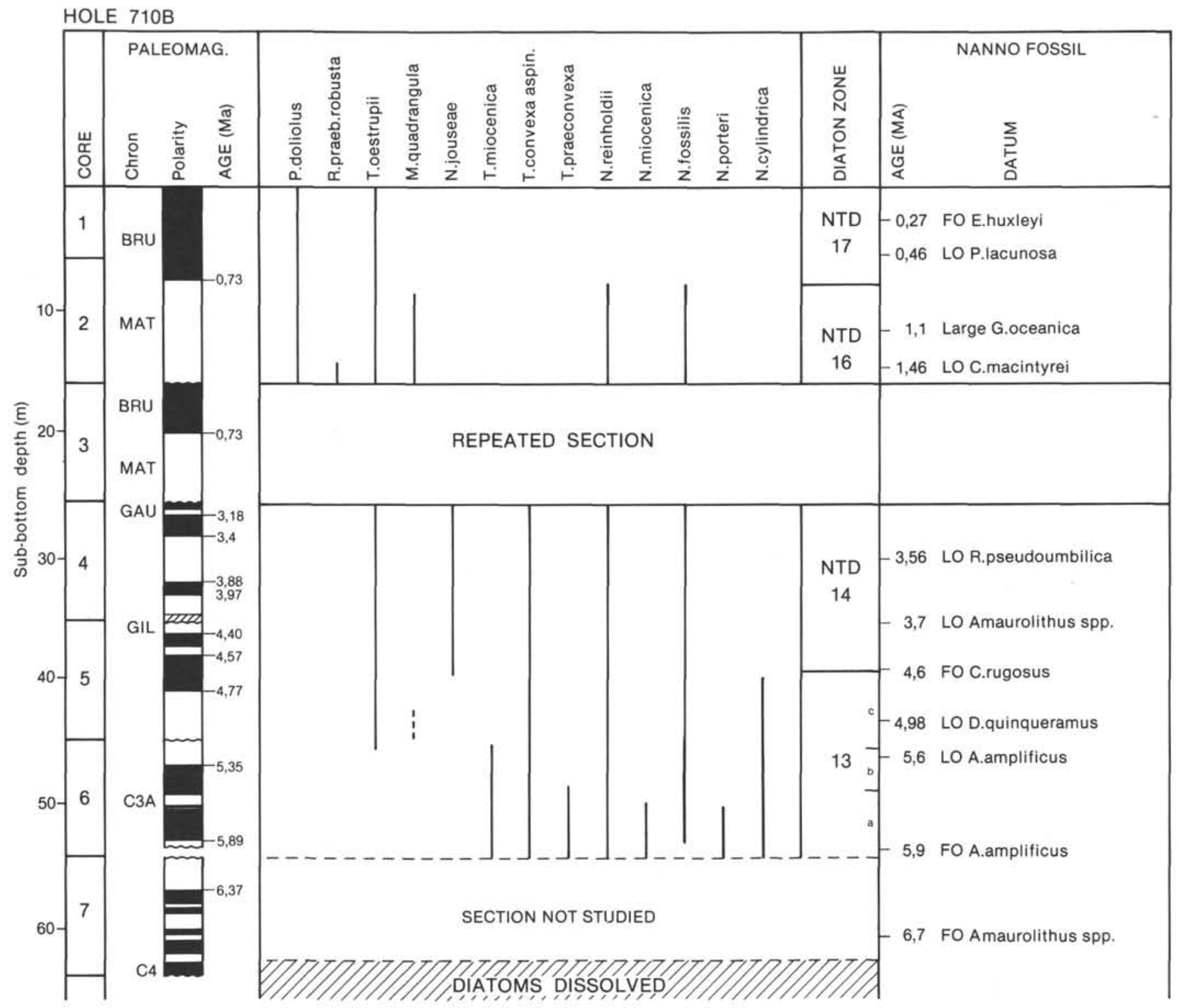

Figure 6 (continued).

occurrence of $M$. elliptica. Schrader (1974) established a Pleistocene $M$. elliptica Zone (TID3) in his Indian Ocean diatom zonation.

The last (common) occurrence of quadrate Mesocena is well defined in all ocean basins. In the Pacific Ocean, the extinction is just below the Brunhes/Matuyama boundary (Barron, 1980a; Sancetta, 1982, 1983). In the North Atlantic region, Baldauf (1986a) showed that the LO of $M$. quadrangula approximates the Matuyama/Brunhes boundary. He suggested that it may be slightly diachronous between the mid- and high-latitude North Atlantic Ocean and also between the North Atlantic and equatorial Pacific oceans.

In the Indian Ocean a good stratigraphic record of Mesocena was obtained in Sites 709 and 710 (Figs. 6 and 7). In the paleomagnetic dated sequence of Site 710 , the LO of quadrate Mesocena is below the Brunhes/Matuyama boundary at an extrapolated age of $0.75 \mathrm{Ma}$. The lower boundary of the quadrate $\mathrm{Me}$ socena acme in the tropical Indian Ocean is less distinct than the extinction level. A sporadic occurrence of Mesocena is noted in the early Pliocene Subzone NTD13c. Quadrate Mesocena have their first consistent appearance in diatom Subzone NTD16a in Sites 709 and 710. In the paleomagnetic record of Hole 710A, the FO is above the Olduvai Event. The Jaramillo Event was not recorded at this site. The first appearance, therefore, cannot be related to Jaramillo. However, Schrader (1974) notes that the base of his $M$. elliptica Zone falls just below the Jaramillo Event.

The acme of quadrate Mesocena is restricted to diatom Subzone NTD16b in Sites 709 and 710. The exact stratigraphic range in relation to the subzonal boundaries is, however, difficult to determine. Thus, $N$. reinholdii has a sporadic occurrence near its extinction that defines the zonal boundary between NTD16b and NTD17.

\section{Thalassiosira yabei var. elliptica}

The only diatom-bearing middle Miocene section recovered during Leg 115 was found in Site 714. This site lacks a paleomagnetic control. The stratigraphic range of a number of selected diatom species was recorded in this site (Fig. 8). All FOs and LOs conform with data from other ocean basins with one 


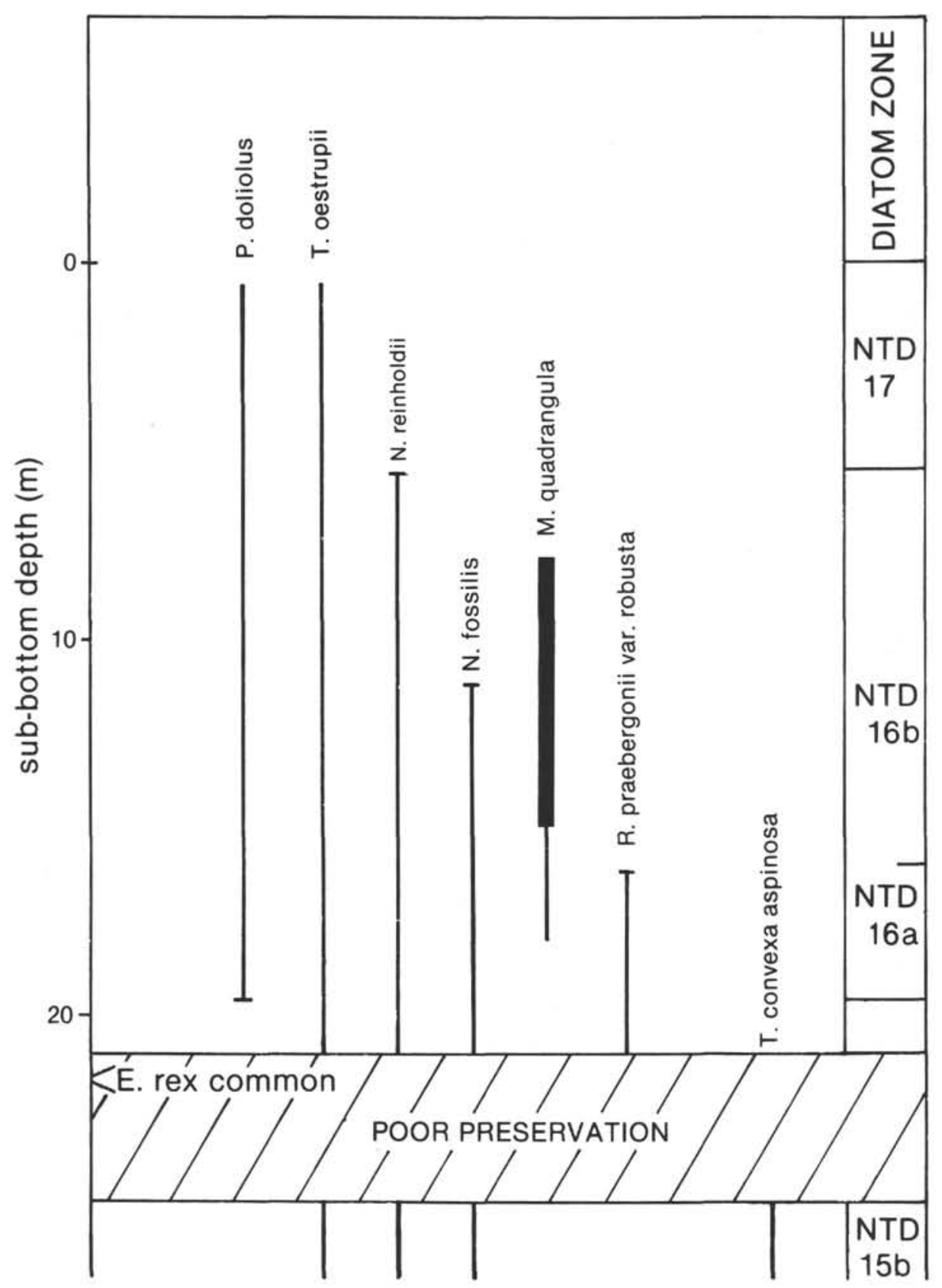

Figure 7. Stratigraphic range of selected diatom species, Hole 709C.

exception. Thalassiosira yabei var. elliptica is present in Subzone NTD10b in the Pacific Ocean with a range between 8.1 and $7.9 \mathrm{Ma}$ (Barron, 1985a). In Site 714 its range is confined to Zone NTD9 with an extrapolated time range of 9.4-9.7 Ma.

\section{Deep-sea Hiatuses and Diatoms}

\section{Deep-sea Hiatuses}

It appears from the biostratigraphic discussion that in the recovered Neogene material of Leg 115 three stratigraphic intervals with rare and poorly preserved diatoms are present above the first appearance of diatoms in middle to late Miocene times.

These intervals correspond to the late Pliocene to early Pleistocene Subzones NTD15c to NTD16a (approximately 2.0 to 1.5 $\mathrm{Ma}$ ), the middle part of the Pliocene Zone NTD14 (approxi- mately 3.4-3.6 Ma), and the early Pliocene Subzone NTD13c (approximately 5.1 Ma). A fourth interval of poor preservation was recognized in the middle to late Miocene Zone NTD9. In the stratigraphic interval below Zone NTD12a, only traces of diatoms were found in the late Miocene Zone NTD11 and NTD10. The exception is Site 714, which is located north of the equator. Here, diatoms are common and well preserved in the late Miocene Zones NTD10 and NTD9, rare to few in NTD8, and rare in Zone NTD7, where they disappear from the sediment column.

Some of the above-mentioned intervals correspond in age to worldwide deep-sea hiatuses of Miocene age (Fig. 2) that have been linked to increased circulation and corrosiveness of bottom waters (Keller and Barron, 1983). These authors noted a strong correlation between calcium carbonate dissolution and most of 


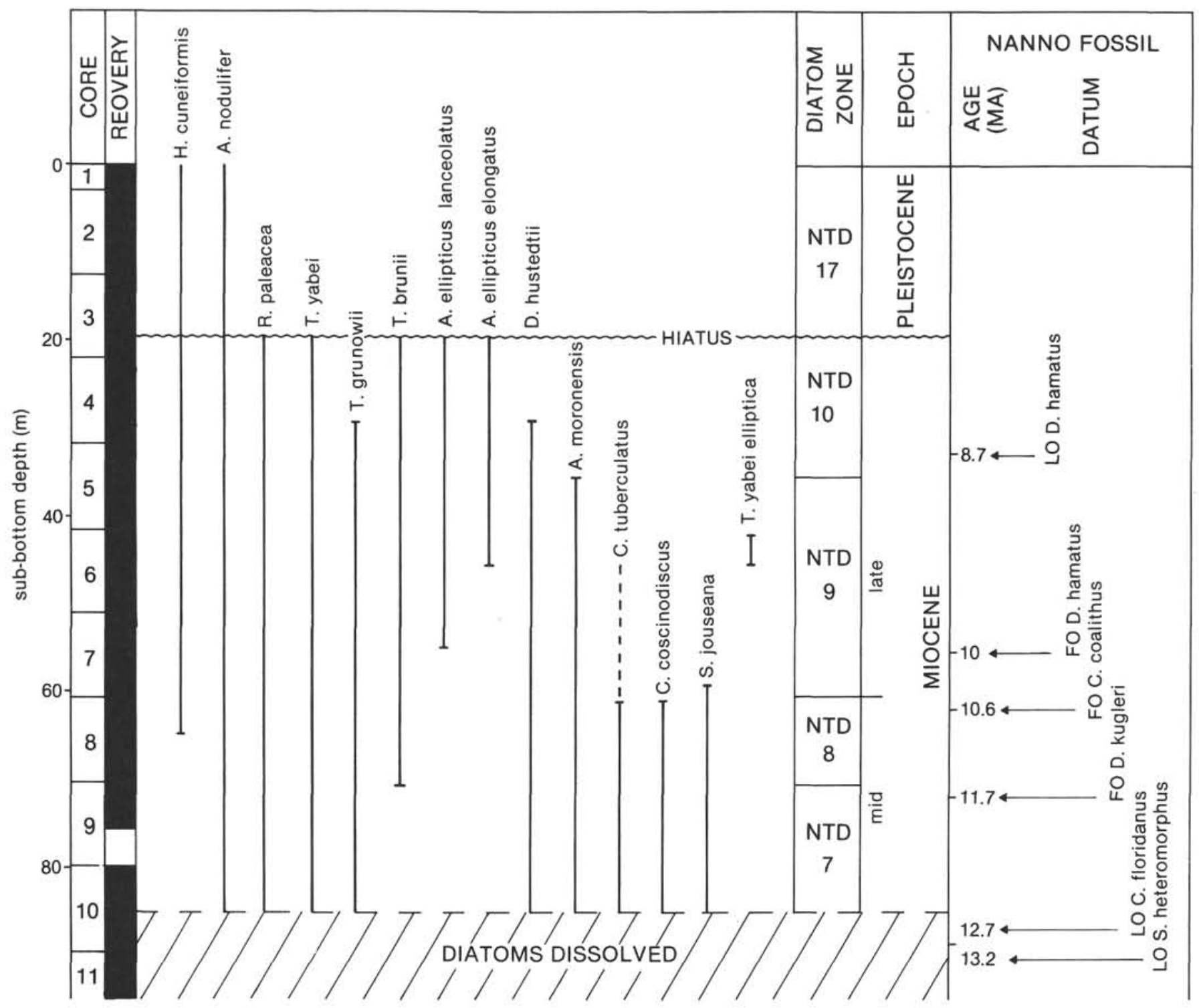

Figure 8. Range of selected diatom species, Hole 714A. The cold-water species Denticulopsis hustedtii is very rare compared with the Pacific Ocean. Nannofossil datums are from D. Rio (pers. comm., December 1988) and datum ages from Okada and Rio (Shipboard Scientific Party, 1988b) with modifications from Backman et al. (this volume). The late Miocene events are uncertain on account of the evidence of sediment redeposition within this stratigraphic interval (Okada and Rio in Shipboard Scientific Party, 1988b).

the observed hiatuses. A correlation between dissolution intervals of biogenic silica and the deep-sea hiatuses was less obvious.

The youngest diatom dissolution interval in the western Indian Ocean-the late Pliocene to earliest Pleistocene of Subzones NTD15c-NTD16a-may be correlated with a distinct late Pliocene-Pleistocene dissolution interval reported by Baldauf (1984) in the North Atlantic. In the western Indian Ocean, the other distinct interval with poor diatom preservation in Zone NTD14 around 3.4-3.6 Ma may correlate with the deep-sea hiatus NH8 of Keller and Barron (1983). A less distinct dissolution interval in Subzone NTD13c is equivalent in time to the deepsea hiatus NH7 of Keller and Barron (1983) and also with a diatom dissolution interval noted in the eastern equatorial Pacific (Barron and Keller, 1982). With the exception of Site 714, diatoms are very rare and poorly preserved in the middle late Miocene sequences below Subzone NTD12b, which marks the top of the deep-sea hiatus NH6. In the North Atlantic, diatoms are generally absent in an interval associated with the base of the $T$. convexa Zone (Baldauf, 1984). This level corresponds in age to the general decline and disappearance of diatoms in the tropical Indian Ocean.

In the northeastern Pacific, Barron (1981) noted dissolution of diatoms in sediments corresponding in age to the deep-sea hiatus NH4. In Site 714 located north of the equator, diatoms are generally well preserved in Zone NTD9, with the exception of the middle part of Zone NTD9, which is equivalent in time to hiatus NH4.

\section{Ethmodiscus rex}

Ethmodiscus rex (Rattray) is a minor, though consistent, component of most studied assemblages. This species, which is one of the most solution-resistant diatoms, forms different types of Ethmodiscus oozes in upper Miocene to Pleistocene sediments of all oceans (Gardner and Burckle, 1975; Mikkelsen, 1977). Hypotheses for the formation of these different types of oozes in- 
clude intense blooms, differential dissolution, redeposition, or a combination of these (Gardner and Burckle, 1975; Mikkelsen, 1977).

Differential dissolution presumably formed the Ethmodiscus-rich interval in Hole $709 \mathrm{C}$, where the late Pliocene section is strongly influenced by silica dissolution (Fig. 7). Similar intervals enriched in $E$. rex have been reported from the equatorial Atlantic (Pokras, 1986; Stabell, 1986), from the North Atlantic (Baldauf, 1986b), and from the eastern Pacific Ocean (Sancetta, 1983).

\section{Benthic and Freshwater Diatoms}

Displaced species of the littoral marine benthic genera $C y$ clotella, Cocconeis, Diploneis, Navicula, and others are fairly common in the open-ocean plankton assemblages of certain stratigraphic intervals. The sparse late Eocene-early Oligocene diatom assemblages in Site 707 are dominated by large and heavily silicified shallow-water species of the genera Navicula, Grammatophora, Biddulphia, and others. Benthic diatoms are also a conspicuous component of the Miocene section of Site 714.

The number of benthic diatoms in Pleistocene sediments of the Indian Ocean is far greater than in the Atlantic and Pacific oceans (Kolbe, 1957). This situation may be caused by differences in the physiographic settings of the ocean basins in that the Indian Ocean is a closed basin surrounded by continents, shallow-water margins, and carbonate platforms. The influence of these margins and platforms is reflected by the diatom assemblages in the surface sediments of the Indian Ocean. Kolbe (1957) found that benthic diatoms were notably more abundant in cores from the Seychelles area in the western Indian Ocean than in any other tropical regions of the Indian Ocean basin.

Freshwater diatoms of the genus Melosira have been found in low abundances throughout most of the Leg 115 sections. The Indian Ocean sediments are poor, however, in freshwater diatoms compared with those of the Atlantic Ocean. This may be attributed to the fact that only a few larger rivers drain into the equatorial Indian Ocean compared with the equatorial Atlantic. Also, the continents surrounding the Indian Ocean basin are rather arid and unsuitable for a greater production of freshwater diatoms.

\section{PALEOCEANOGRAPHY}

\section{Diatom Abundance and Paleoproductivity}

The abundance of biogenic silica (opal) in the surface sediments of the world oceans is high in areas of upwelling and primary productivity (Leinen, 1979; Molina-Cruz and Price, 1977; Leinen et al., 1986; Pokras and Molfino, 1986; Pokras, 1986). Surface-water productivity exerts a primary control on the abundance of siliceous microfossils in the sediments (Schink et al., 1974; Broecker and Peng, 1982; Pokras and Molfino, 1986) by controlling the supply rate of siliceous valves to the seafloor and the silica saturation level of the pore waters. Most of the siliceous skeletons produced in the photic zone dissolve before entering the sedimentary record because of undersaturation of the oceans with respect to opal and to dissolution in the uppermost centimeters of the sediments (Lisitzin, 1972, 1985; Heath, 1974; Berger, 1976; Van Bennekom and Berger, 1984). The impact of this dissolution on the fossil record is, however, a function of relative rather than absolute loss of siliceous valves (Pokras, 1986). The rates of biogenic silica accumulation through time are, therefore, a general indication of the intensity of upwelling in equatorial regions and hence of productivity changes.

A qualitative assessment of the diatom abundance was recorded in the latitudinal transect of sites from $13^{\circ} \mathrm{S}$ to $5^{\circ} \mathrm{N}$ (Fig. 9). Two major periods of high biogenic silica accumulation oc- curred in the western equatorial Indian Ocean during the last 50 m.y.: the middle Eocene-early Oligocene period of the Paleogene, and the late Miocene-early Pliocene period of the Neogene. In contrast, the lower and middle Miocene sediments $(\sim 21-10 \mathrm{Ma})$ in sites located south of the equator are entirely lacking in siliceous microfossils.

The evolutionary history of diatom assemblages in the western Indian Ocean is stepwise, and the first Tertiary occurrence is subtle. Rare and poorly preserved diatoms have a sporadic occurrence in the Paleogene siliceous assemblages (Fig. 3; and Fenner and Mikkelsen, this volume). These assemblages are entirely dominated by radiolarians (Fig. 10) and siliceous sponge spicules. The radiolarians, which are not primary producers, are abundant and well preserved, and also the siliceous sponge spicules are diversified and well developed. The late Paleogene occurrence of diatoms is apparently not the result of a brief period with more favorable conditions for the preservation of biogenic silica, because radiolarians are equally well preserved throughout these sections. Rather, the spatial occurrence of diatoms might witness enhanced growth conditions for diatoms.

Diatoms disappear entirely from the sedimentary record in early Oligocene around $30 \mathrm{Ma}$, whereas radiolarians and sponge spicules persist in the early Miocene until approximately $21 \mathrm{Ma}$ (Fig. 10) in sites south of the equator. The early Miocene and most of the middle Miocene is characterized by a total absence of opaline silica. Siliceous microfossils reappear in the sedimentary record in the late Miocene. Radiolarians reappear at approximately $10 \mathrm{Ma}$ and diatoms around $8 \mathrm{Ma}$ (Fig. 10). In contrast, Site 714, which has a present-day location north of the equator, furnishes biogenic silica presented by radiolarians and sponge spicules in the lower and middle Miocene sediments. The Neogene assemblages are totally dominated by diatoms in contrast to the radiolarian-dominated Paleogene assemblages. Neogene diatoms are only outnumbered by radiolarians and sponge spicules in poorly preserved assemblages due to differences in dissolution resistance of the three groups (Schrader, 1974; Mikkelsen, 1978).

The succession in siliceous assemblages from dominance of radiolarians in the Paleogene to dominance by diatoms in the Neogene of Leg 115 sites is a mirror of larger-scale changes. $\mathrm{Pa}$ leogene siliceous deposits are dominated on a worldwide scale by thickly silicified radiolarians, whereas the diatom group proliferates in the middle to late Miocene at the expense of radiolarians. This might be a result of a general decline in the silica concentration of the oceans and of the diatoms having evolved a more efficient mechanism of precipitating the scarce silica from the oceans into their more thinly silicified skeletons in comparison with the more silica-consuming radiolarians (Harper and Knoll, 1975).

\section{Neogene Paleoceanography}

\section{Early Miocene}

Early Miocene sediments recovered south of the equator during Leg 115 are entirely lacking in siliceous microfossils. The severe changes in the Neogene global climate, coupled with the tectonic evolution of the Indian Ocean basin, had a profound impact on the Neogene planktonic diatom assemblages and shaped their stratigraphic distribution. The early Miocene tropical circulation in the Indian Ocean was part of a low-latitude circumequatorial flow through the Pacific and Indian oceans and possibly the Mediterranean Sea (Hsü, 1977). During this period, biogeographic boundaries were gradational rather than sharp and temperature gradients were weak (Wright and Thunell, 1988).

A survey of Neogene siliceous sediments in the world oceans has revealed that biogenic silica is nearly absent in the Miocene 


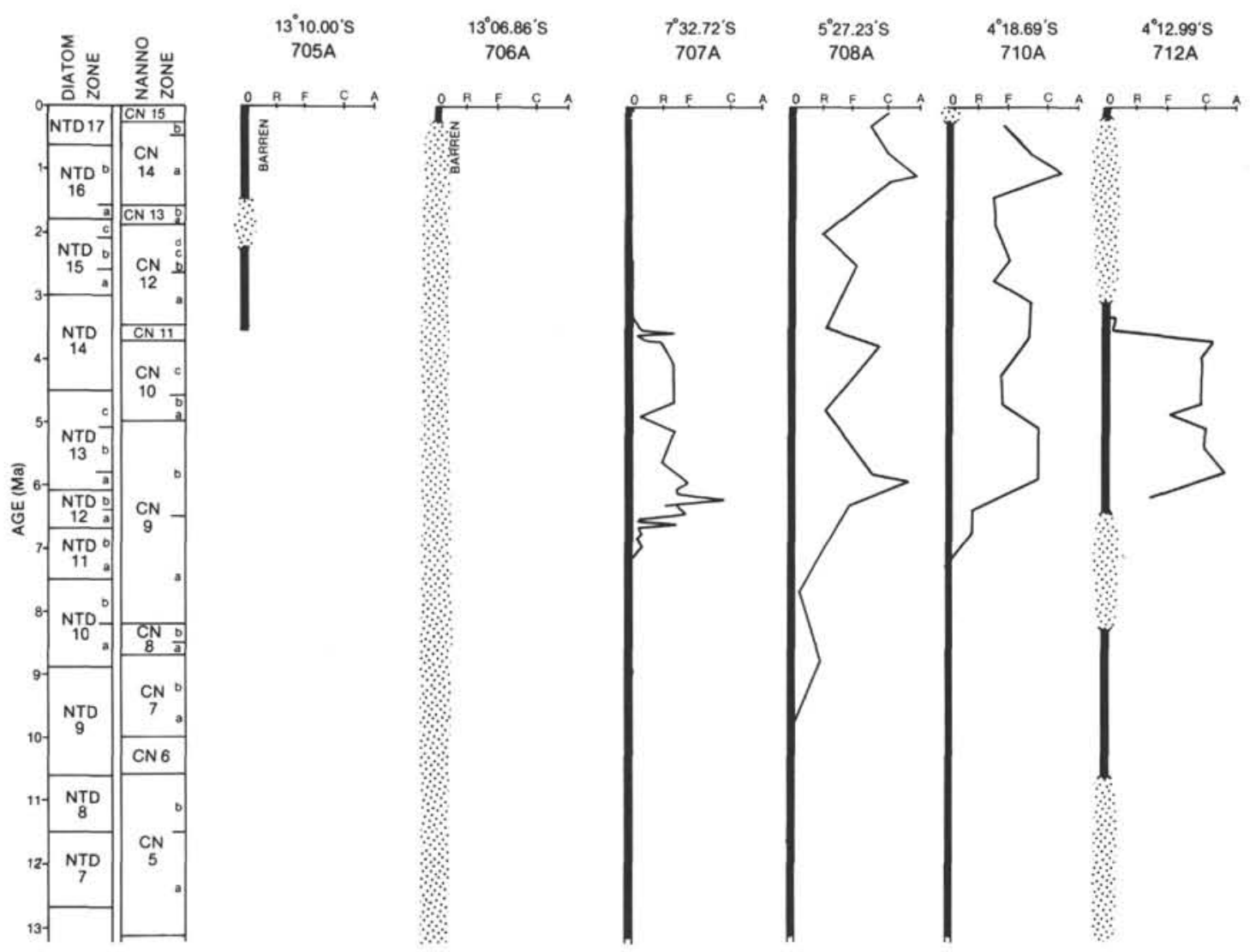

Figure 9. Relative abundances of Neogene diatoms plotted vs. age. A dotted interval represents a hiatus. The sites are arranged according to latitude. All sites south of the equator are within a longitude of $59^{\circ}-61^{\circ} \mathrm{E}$ except for Sites 712 and 713 , which have a longitude of $73^{\circ} \mathrm{E}$. The present-day high-productivity area is confined to a belt from the equator to $5^{\circ} 5$. In late Miocene-early Pliocene time, this belt was located between $4^{\circ} \mathrm{S}$ and $7^{\circ} \mathrm{S}$.

prior to $16 \mathrm{Ma}$ in the Indian and Pacific oceans and at the same time the North Atlantic was dominated by siliceous sedimentation (Berger, 1970; Keller and Barron, 1983; Barron and Baldauf, 1989). The lack of siliceous valves in the Leg 115 sites between approximately $21 \mathrm{Ma}$ and $10 \mathrm{Ma}$ may reflect this silica deficiency and thus a highly reduced productivity of siliceous microorganisms in the western part of the tropical Indian Ocean caused by the trapping of silica in the Atlantic Ocean. Woodruff and Savin (1989) noted that during the early Miocene time the Indian Ocean was affected by the outflow of a warm saline plume from the eastern Tethys. This condition could be an additional limiting factor for the diatom productivity.

\section{Middle Miocene}

With the subsidence of the Faero-Iceland Ridge and the formation of the North Atlantic Deep Water in late middle Miocene (Blanc et al., 1980) the production of silica-rich Antarctic Deep Water was strengthened and displaced into other ocean basins. A notable transfer of silica accumulation from the Atlantic to the Pacific and Indian oceans was presumably a result of this silica switch (Keller and Barron, 1983; Barron and Baldauf, 1989). It triggered the opal production in the equatorial fertile belt of the western Indian Ocean and hence the reappearance of siliceous microfossils in the sedimentary record of Leg 115. The initiation of the Indian Ocean monsoonal upwelling in the middle Miocene (Leg 117 Shipboard Scientific Party, 1988) presumably enhanced this productivity.

Of all the middle Miocene sections recovered during Leg 115 , only Site 714 furnishes siliceous microfossils. During the northward migration of the Indian plate, this site passed under the equatorial high-productivity belt in middle Miocene times. All other sites were south of the productive zone and are thus barren of middle Miocene diatoms (Fig. 3). Variations in the diatom assemblages of Site 714 give a first approximation of productivity and oceanographic changes in the middle Miocene Indian Ocean. Diatoms have their first Neogene appearance in Site 714 around $13 \mathrm{Ma}$, where they are rare and poorly preserved. The abundance increases upsection, and around $12 \mathrm{Ma}$ a typical cold-water species, Coscinodiscus marginatus, is introduced to the diatom assemblages (Fig. 11). This species has a peak abundance around $10 \mathrm{Ma}$ and then tails off.

The sudden appearance of this cold-water species in equatorial regions of the Indian Ocean points to the free exchange of surface water masses between high and low latitudes and hence weakened thermal gradients. Barron (1985b) also found an incursion of cold-water diatoms in the middle Miocene of the $\mathrm{Pa}$ cific Ocean. These cold-water diatoms were represented by $C$. marginatus, Actinocyclus ingens, and by common Denticulopsis hustedtii, which in certain intervals reached a relative abundance of $50 \%$. In the Indian Ocean sediments, the relative abundance of cold-water diatoms never exceeds $5 \%$. This indicates that the influence of high-latitude surface waters on equatorial regions was less pronounced in the Indian Ocean compared with the Atlantic and Pacific oceans and, thus, that the middle Miocene thermal gradients were stronger in the Indian Ocean basin than in the Pacific and Atlantic basins.

The rapid decrease in C. marginatus is followed by an increase around $10 \mathrm{Ma}$ in the abundance of the pennate species of 

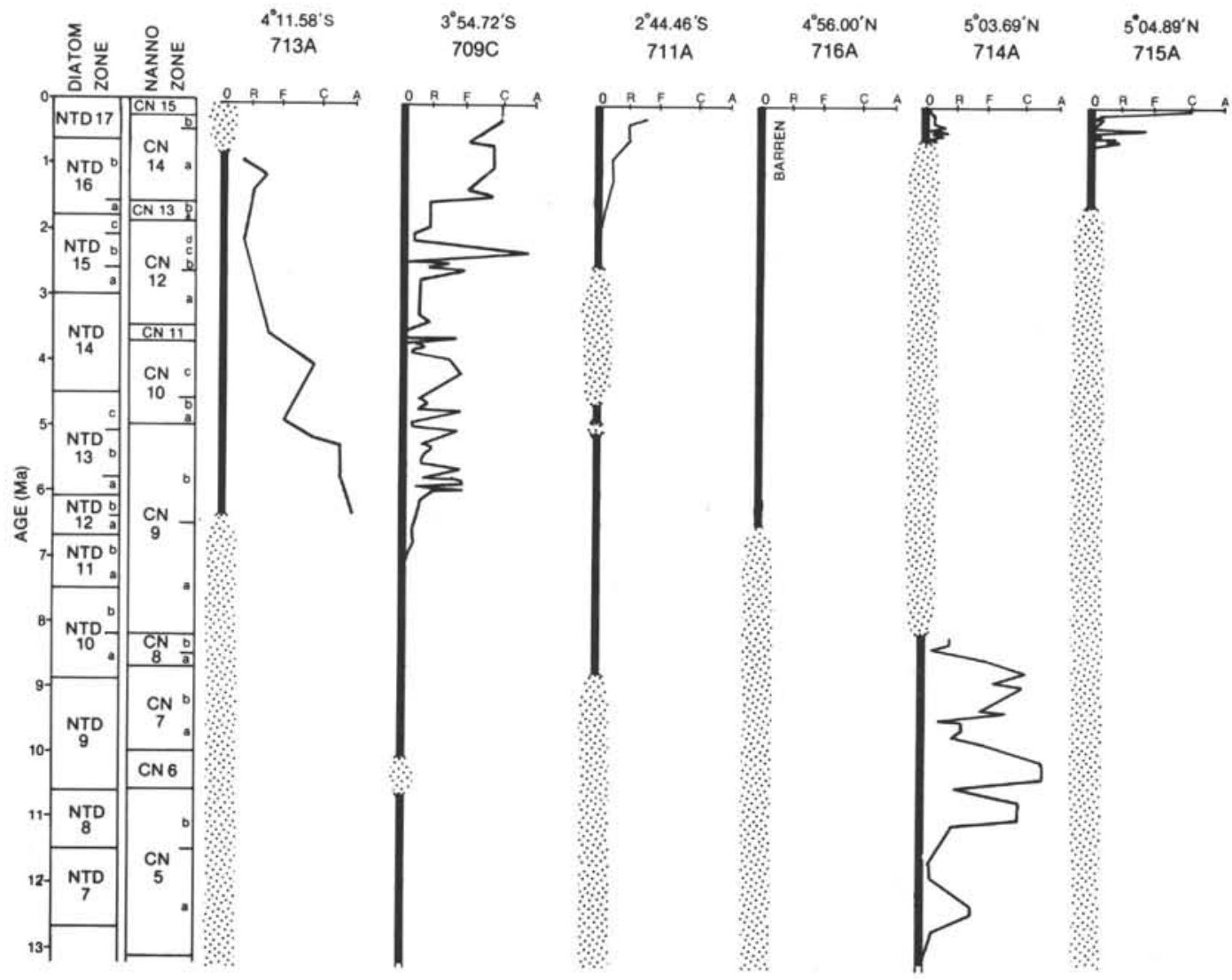

Figure 9 (continued).

Thalassionema and Thalassiothrix (hereafter referred to as the Thalassionema group). The Thalassionema group, which is a characteristic constituent of plankton in areas of upwelling and high primary productivity (Schuette and Schrader, 1981), implies a period of high productivity in the fertile belt of the western part of the equatorial Indian Ocean. The Thalassionema increase following the decline of $C$. marginatus reflects the impact of the middle Miocene polar cooling with the formation of strong thermal gradients and the disconnection of high- and low-latitude surface waters. Increased vigor of the ocean circulation, which was triggered by the polar glaciations, apparently stimulated productivity in the equatorial Indian Ocean. A contemporaneous high-productivity period is reported from the equatorial Pacific Ocean (Sancetta, 1982; Barron, 1985b).

Activity in the Indian Ocean bottom waters is further witnessed by the presence of frequent benthic diatoms of the genera Grammatophora, Cyclotella, Navicula, and others in the middle Miocene sedimentary record (Fig. 11). Because benthic diatoms are limited to the photic zone of shallow-water environments, their presence in sediments from greater depths is an indication of redeposition. In the Miocene section of Site 714, the maximal abundance of benthic diatoms around $10 \mathrm{Ma}$ corresponds in age to a drastic drop in the eustatic sea level (Haq et al., 1987) and thus to a widespread erosional event. In central Pacific deep-sea sediments, a high abundance of neritic calcareous microfossils also corresponds to low eustatic sea levels (Thiede, 1981).

The high middle Miocene abundance of benthic diatoms in Site 714 is followed by a high abundance of the productivity-indicating Thalassionema group. This diatom productivity might have resulted from the sea-level rise that followed the $10-\mathrm{Ma}$ drop, as witnessed by the benthic diatoms. A transgressive phase could thus have sustained productivity by eroding sediments from coastal areas as well as by enriching the oceans with productivity-increasing nutrients. The intense middle Miocene diatom productivity ceased around $8.5 \mathrm{Ma}$ in Site 714 when the Indian plate moved north of the equator. With the middle Miocene closure of the circumglobal connections (Kennett et al., 1985), equatorial surface circulation of the Indian Ocean began to resemble the present-day configuration.

\section{Late Miocene-Early Pliocene}

The early late Miocene sections of Leg 115 are all characterized by either the lack of diatoms or by a rare occurrence of poorly preserved diatoms. In contrast, the late Miocene-early Pliocene period provides well-developed diatom assemblages.

Two pulses of increased diatom productivity are recognized within the late Neogene. The first appears in the late Miocene around 6-4.5 $\mathrm{Ma}$, in which well-preserved diatom assemblages with high diversities are established in the western tropical Indian Ocean. According to the recovered sequences, the increased accumulation of biogenic silica is restricted to a fertile belt located between approximately $4^{\circ} \mathrm{S}$ and $7^{\circ} \mathrm{S}$ (Fig. 9). Sites north of this belt have a low abundance of late Miocene-early Pliocene biogenic silica.

Site coverage south of the belt is poor, but the reduced productivity signal in Site 707 at $7^{\circ} \mathrm{S}$ compared with the sites located slightly further to the north is used to delineate the southern boundary of the late Miocene-early Pliocene high-fertility belt. Plate movements ceased during the high-productivity period in the late Miocene-early Pliocene, and since then the configuration of the Indian Ocean basin has not altered significantly (Hamilton, 1979). 


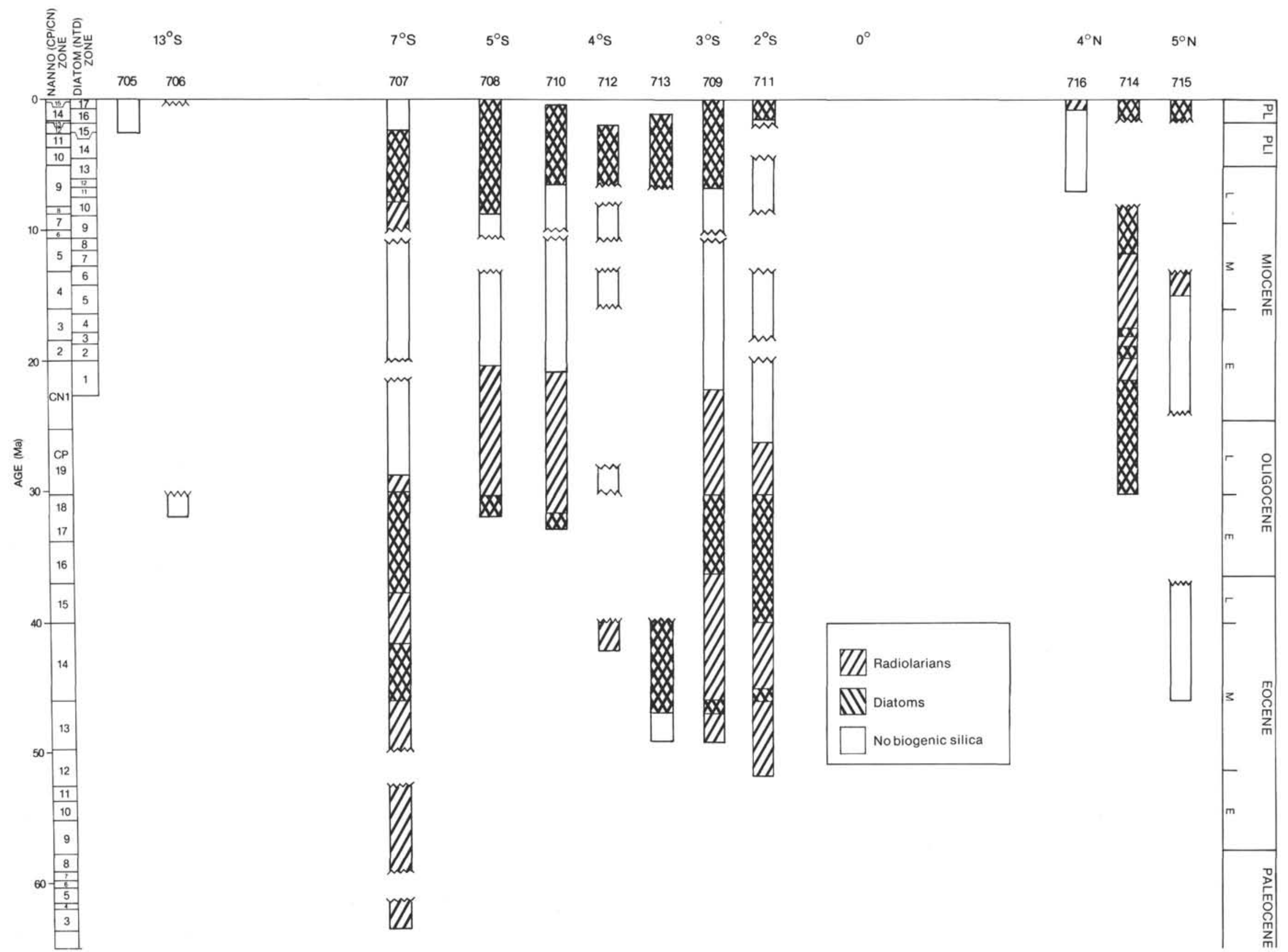

Figure 10. Stratigraphic distribution of biosiliceous sediments of Leg 115 sites. The Paleogene siliceous assemblages are entirely dominated by radiolarians and sponge spicules, and diatoms are rare. The lower Miocene and lower middle Miocene sediments are barren of biogenic silica south of the equator. With the reappearance of siliceous microfossils in the late Miocene-early Pliocene, diatoms become the dominant constituent of the assemblages. In Site 714, which has a present-day location north of the equator, biogenic silica is present in the lower and middle Miocene 


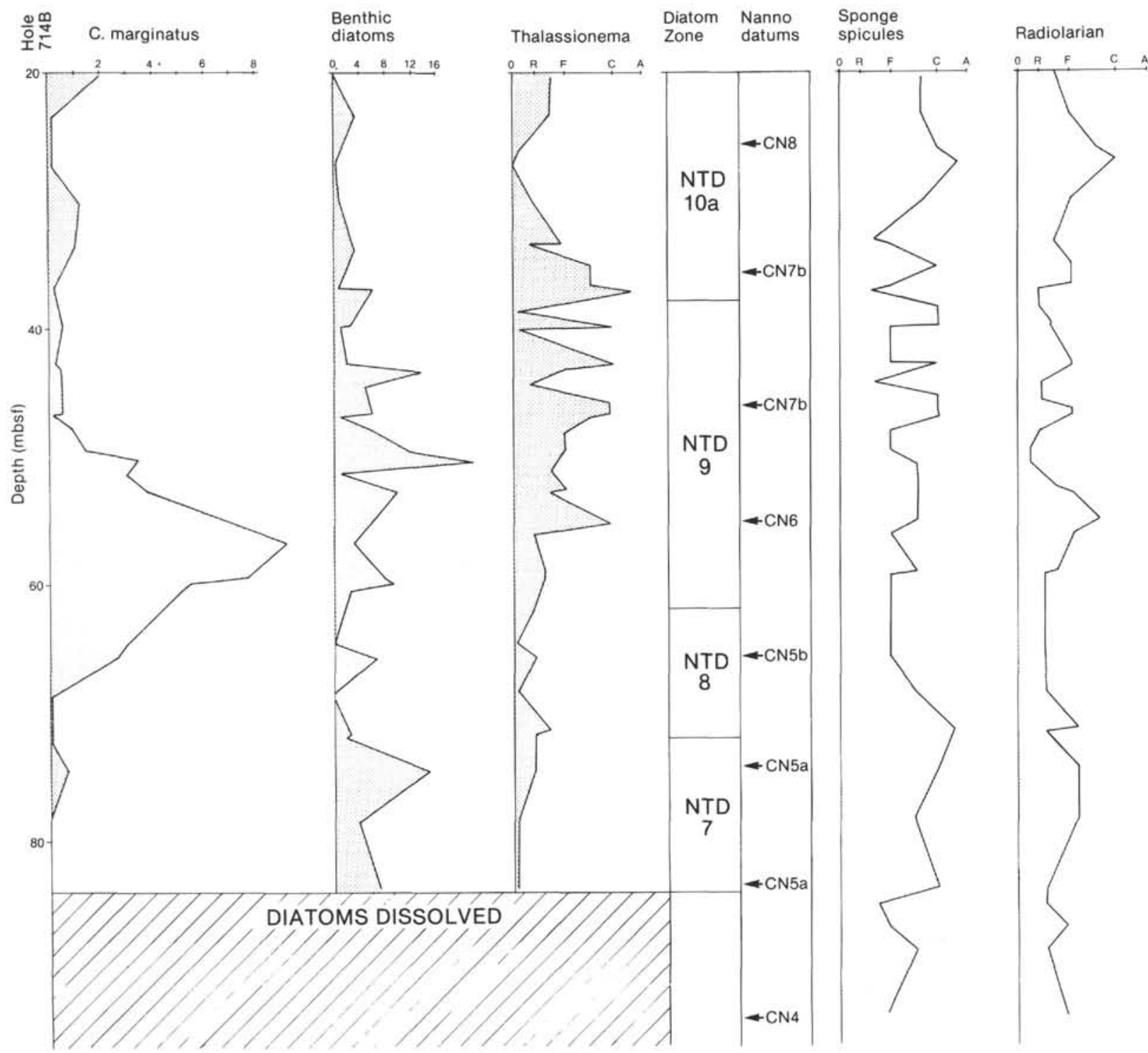

Figure 11. Stratigraphic distribution and relative abundance of the cold-water diatom C. marginatus, benthic diatoms, Thalassionema sp., radiolarians, and sponge spicules in the Miocene section of Hole 714B. The abundances are based on qualitative estimates. A hiatus at 20 mbsf spans the interval from the late Miocene to the Pleistocene.

\section{Late Pliocene}

The intense late Miocene-early Pliocene accumulation of biogenic silica is replaced in all sites by a late Pliocene decline in the production of biogenic silica. It is witnessed by a decrease in the abundance of diatoms and in particular by a decrease of the Thalassionema group. A similar decline, which continues into the Quaternary, is described for the equatorial Pacific Ocean (Leinen, 1979). This decline was caused by an early Pliocene shift in the site of opal accumulation from equatorial regions to the Antarctic Convergence, where opal is trapped in the area of the Polar Front (Brewster, 1980).

With the middle and late Pliocene high-latitude cooling associated with the Northern hemisphere glaciation, equatorial surface-water temperatures remains stable but there is a northward migration of the tropical-subtropical faunal boundary and the emergence of a polar province in the Indian Ocean (Wright and Thunell, 1988).

\section{Pleistocene}

The Pleistocene period is characterized by a fairly high accumulation of biogenic silica within the fertile belt of the western Indian Ocean and especially by an intense productivity pulse around $1 \mathrm{Ma}$ (Fig. 9). After this pulse, all sites with diatombearing upper Pleistocene sediments seem to signal yet another slight increase up to the present. This might indicate that presentday productivity is strengthened compared with the situation just a few hundred thousand years ago. The present-day fertile belt is confined to the area of Sites 708 and 709 and thus appears to be restricted to a belt between $5^{\circ} \mathrm{S}$ and $3^{\circ} \mathrm{S}$ of the equator. Sites 705, 706, and 707 are located south of the present fertile belt, according to the diatom data. This implies a northward shift of the high-productivity area of $1^{\circ}-2^{\circ}$ since the late Miocene-early Pliocene period. North of the equator, Pleistocene diatom productivity appears highly reduced, as witnessed by the sediment record of Sites 714 and 715 . Site 716, located on the 
carbonate platform of the Maldives Ridge, is totally barren of siliceous microfossils.

The distribution of diatoms in the recovered surface sediments reflects the present-day circulation in the Indian Ocean. This circulation is grouped into three major components: the Antarctic circumpolar waters, the southern subtropical gyre, and the northern reversing monsoonal gyre (Wyrtki, 1973). Surface waters north of the gyre boundary are nutrient rich and highly productive whereas productivity is low in the nutrient-depleted subtropical gyre south of the boundary (Hutson, 1977; Wright and Thunell, 1988). According to the diatom distribution in the Leg 115 sites, the gyre boundary is located between $5^{\circ} \mathrm{S}$ and $7^{\circ} \mathrm{S}$ in the tropical part of the western Indian Ocean.

\section{Plate Tectonics and Diatom Productivity}

In view of the changes in the ocean circulation inferred from the plate movements, it could be speculated that silica for the intense middle Eocene to early Oligocene silica production in the western Indian Ocean was derived from the Southern Ocean. In contrast, the silica input for the second major phase in the latest Miocene-early Pliocene was derived from a the steadily increasing amount of fluvially derived sediments that originated from the plate collision between the Indian and Eurasian plates. Thus, the productivity of diatoms and other siliceous organisms would be related to an overall tectonic framework in which intense seafloor spreading and plate collisions with uplift and erosion would trigger the formation of the vital silica for the surface waters of the oceans. A second-order event is the influence of sealevel changes on diatom productivity (Harper and Knoll, 1975). As discussed above, a transgressive phase is likely to erode sediments from coastal areas and thus enrich the oceans with productivity-increasing nutrients.

\section{TAXONOMIC NOTES}

Most species encountered in the Leg 115 material have been described and illustrated by numerous workers. The reader is referred to Akiba (1986), Baldauf (1985, 1986a) Barron (1985a, 1985c), Burckle (1972), Fenner (1985), and Schrader (1973, 1974), and references therein for taxonomic descriptions, illustrations, and references.

\section{SUMMARY}

The gross abundance pattern of biogenic silica in the sedimentary record of Leg 115 exhibits marked variations. The Eocene and early Oligocene biosiliceous sediments are dominated by radiolarians and sponge spicules, and diatoms are rare and poorly preserved. All sections of late Oligocene-early Miocene age to late Miocene age are barren of siliceous microfossils in the sites located south of the equator. Biogenic silica reappears in the sedimentary record of late middle and late Miocene ages. Full abundance is found in latest Miocene-early Pliocene sections, where the siliceous assemblages are dominated by diatoms.

In the suite of sites in the Mascarene Plateau area south of the equator (Sites 707-711), diatoms have their first common reappearance around $8 \mathrm{Ma}$. At Site 714 located $5^{\circ} \mathrm{N}$ of the equator, the first common occurrence is in the late middle Miocene around $13 \mathrm{Ma}$. The earlier occurrence of diatoms in the northerly located site is a result of the plate-tectonic passage of Site 714 under the high productivity belt in late middle Miocene times. Thus, the first upsection occurrence of diatoms in the Leg 115 sites outlines the history of the high fertility belt in the Indian Ocean and of the northward movement of the Indian Plate across this belt.

In the late Miocene-early Pliocene, the high-productivity area of the western Indian Ocean was confined to a belt between $4^{\circ} \mathrm{S}$ and $7^{\circ} \mathrm{S}$. The present-day productivity zone is within $5^{\circ} \mathrm{S}$ of the equator. This general productivity pattern of the equatorial Indian Ocean was established when the Indian plate moved north of the equator around $10 \mathrm{Ma}$ and the modern equatorial circulation system was created.

\section{ACKNOWLEDGMENTS}

The working conditions provided by the co-chiefs J. Backman and R. Duncan, and the cooperation and cheerful atmosphere radiated by all fellow participants aboard JOIDES Resolution made Leg 115 a highly inspiring cruise. Even work at the sampling table during the cruise was enjoyable when the watch was announced by songs from a barbershop quartet.

The unselfish help and support from J. Barron during this study as well as from my very first rendezvous with diatoms, is most deeply appreciated. I also thank D. Bukry and J. Fenner for discussions and help throughout the course of this study.

The Danish Natural Science Research Council financed the cruise participation. Appreciation is further due to C. Geisnaes, B. Hammerstrøm, I. Nørgaard, and I. M. Jensen, all at the Geological Survey of Denmark for technical assistance. The administration of the Geological Survey of Denmark is thanked for the permission to participate in the Ocean Drilling Program.

\section{REFERENCES}

Akiba, F., 1986. Middle Miocene to Quaternary diatom biostratigraphy in the Nankai Trough and Japan Trench, and modified lower Miocene through Quaternary diatom zones for middle-to-high latitudes of the North Pacific. In Kagami, H., Karig, D., Coulbourn, W. T., et al., Init. Repts. DSDP, 87: Washington (U.S. Govt. Printing Office), 393-481.

Baldauf, J. G., 1984. Cenozoic diatom biostratigraphy and paleoceanography of the Rockall Plateau region, North Atlantic, Deep Sea Drilling Project Leg 81. In Roberts, D. G., Schnitker, D., et al., Init. Repts. DSDP, 81: Washington (U.S. Govt. Printing Office), 439478.

1985. A high-resolution late Miocene-Pliocene diatom biostratigraphy for the eastern equatorial Pacific. In Mayer, L., Theyer, F., Thomas, E., et al., Init. Repts. DSDP, 85: Washington (U.S. Govt. Printing Office), 457-475.

1986a. Diatom biostratigraphy of the middle- and high-latitude North Atlantic Ocean, Deep Sea Drilling Project Leg 94. In Ruddiman, W. F., Kidd, R. B., Thomas, E., et al., Init. Repts. DSDP, 94, Pt. 2: Washington (U.S. Govt. Printing Office), 729-762. 1986b. Biostratigraphic and paleoceanographic interpretation of lower and middle Miocene sediments, Rockall Plateau Region, North Atlantic Ocean. In Ruddiman, W. F., Kidd, R. B., Thomas, E., et al., Init. Repts. DSDP, 94, Pt. 2: Washington (U.S. Govt. Printing Office), 1033-1043.

Barron, J. A., 1980a. Upper Pliocene and Quaternary diatom biostratigraphy of Deep Sea Drilling Project Leg 54, tropical eastern Pacific. In Rosendahl, B. R., Hekinian, R., et al., Init. Repts. DSDP, 54: Washington (U.S. Govt. Printing Office), 455-485.

$1980 \mathrm{~b}$. Lower Miocene to Quaternary diatom biostratigraphy of Leg 57, off northeastern Japan, Deep Sea Drilling Project. In Scientific Party, Init. Repts. DSDP, 56, 57, Pt. 2: Washington (U.S. Govt. Printing Office), 641-685.

1981. Late Cenozoic diatom biostratigraphy and paleoceanography of the middle-latitude eastern North Pacific, Deep Sea Drilling Project Leg 63. In Yeats, R. S., Haq, B. U., et al., Init. Repts. DSDP, 63: Washington (U.S. Govt. Printing Office), 507538.

1983. Latest Oligocene through early middle Miocene diatom biostratigraphy of the eastern tropical Pacific. Mar. Micropaleontol., 7:487-515.

1985a. Late Eocene to Holocene diatom biostratigraphy of the equatorial Pacific Ocean, Deep Sea Drilling Project Leg 85. In Mayer, L., Theyer, F., Thomas, E., et al., Init. Repts. DSDP, 85: Washington (U.S. Govt. Printing Office), 413-456.

$1985 \mathrm{~b}$. Diatom paleoceanography and paleoclimatology of the central and eastern equatorial Pacific between 18 and $6.2 \mathrm{Ma}$. In Mayer, L., Theyer, F., Thomas, E., et al., Init. Repts. DSDP, 85: Washington (U.S. Govt. Printing Office), 935-945. 
1985c. Miocene to Holocene planktic diatoms. In Bolli, H. M., Saunders, J. B, and Perch-Nielsen, K. P. (Eds.), Plankton Stratigraphy: Cambridge (Cambridge Univ. Press), 763-809.

Barron, J. A., and Baldauf, J. G., 1989. Tertiary cooling steps and paleoproductivity as reflected by diatoms and biosiliceous sediments. In Berger, W. H., Smetacek, V. S., and Werfer, G. (Eds.), Dahlen Workshop Reports, Life Sciences Research Report, 44:341-354.

Barron, J. A., and Keller, G., 1982. Widespread Miocene deep-sea hiatuses: coincidence with periods of global cooling. Geology, 10:577581.

Barron, J. A., Keller, G., and Dunn, D. A., 1985a. A multiple microfossil biochronology for the Miocene. Mem. Geol. Soc. Am., 163:2136.

Barron, J. A., Nigrini, C. A., Pujos, A., Saito, T., Theyer, F., Thomas, E., and Weinreich, N., 1985b. Synthesis of biostratigraphy, central equatorial Pacific, Deep Sea Drilling Project Leg 85: refinement of Oligocene to Quaternary biochronology. In Mayer, L., Theyer, F., Thomas, E., et al., Init. Repts. DSDP, 85: Washington (U.S. Govt. Printing Office), 905-934.

Berger, W. H., 1970. Biogenous deep-sea sediments: fractionation by deep-sea circulation. Geol. Soc. Am. Bull., 81:1385-1401.

1976. Biogenous deep-sea sediments: production, preservation, and interpretation. In Riley, J. P., and Chester, R. (Eds.), Chemical Oceanography (Vol. 5): New York (Academic Press): 265388 .

Berggren, W. A., Kent, D. V., and Flynn, J. J., 1985a. Jurassic to Paleogene: Part 2, Paleogene geochronology and chronostratigraphy. In Snelling, N. J. (Ed.), The Chronology of the Geologic Record. Geol. Soc. Mem. (London), 10:141-195.

Berggren, W. A., Kent, D. V., and Van Couvering, J. A., 1985b. The Neogene: Part 2, Neogene geochronology and chronostratigraphy. In Snelling, N. J. (Ed.), The Chronology of the Geological Record. Geol. Soc. Mem. (London), 10:211-260.

Blanc, P. L., Rabussier, D., Vergnaud-Grazzini, C., and Duplessy, J. C., 1980. North Atlantic deep water formed by the later middle Miocene. Nature, 283:553-555.

Brewster, N. A., 1980. Cenozoic biogenic silica sedimentation in the Antarctic Ocean. Geol. Soc. Am. Bull., 91:337-347.

Broecker, W. S., and Peng, T.-H. 1982. Tracers in the Sea: New York (Eldigio Press).

Bukry, D., 1985. Tropical Pacific silicoflagellate zonation and paleotemperature trends of the late Cenozoic. In Mayer, L., Theyer, F., Thomas, E., et al., Init. Repts. DSDP, 85: Washington (U.S. Govt. Printing Office), 447-497.

Bukry, D., and Foster, J. H., 1973. Silicoflagellate and diatom stratigraphy, Leg 16, Deep Sea Drilling Project. In van Andel, T. H., Heath, G. R., et al., Init. Repts. DSDP, 16: Washington (U.S. Govt. Printing Office), 815-871.

Burckle, L. H., 1972. Late Cenozoic planktonic diatom zones from the eastern equatorial Pacific. Nova Hedwig. Beifht., 39:217-246.

1977. Pliocene and Pleistocene diatom datum levels from the equatorial Pacific. Quat. Res., 7:330-340.

1978. Early Miocene to Pliocene diatom datum level for the equatorial Pacific. Geol. Res. Dev. Cent., Rep. Indones., Spec. Publ., 1:25-44.

Burckle, L. H., Keigwin, L. D., and Opdyke, N. D., 1982. Middle and late Miocene stable isotope stratigraphy; correlation to the paleomagnetic reversal record. Micropaleontology, 28:329-334.

Burckle, L. H., and Opdyke, N. D., 1977. Late Neogene diatom correlations in the Circum-Pacific. Proc. First Int. Congr. Pacific Neogene Stratigr. (Tokyo, 1976): Tokyo (Kaiyo Shupan Co. Ltd.), 255284.

Burckle, L. H., and Trainer, J., 1979. Middle and late Pliocene diatom datum levels from the central Pacific. Micropaleontology, 25:281293.

Fenner, J., 1984. Eocene-Oligocene planktic diatom stratigraphy in the low latitudes and high southern latitudes. Micropaleontology, 30: 319-342.

1985. Late Cretaceous to Oligocene planktic diatoms. In Bolli, H. M., Saunders, J. B., and Perch-Nielsen, K. P. (Eds.), Plankton Stratigraphy: Cambridge (Cambridge Univ. Press.), 713-762.

Gardner, J. V., and Burckle, L. H., 1975. Upper Pleistocene Ethmodiscus rex oozes from the eastern equatorial Atlantic. Micropaleontology, 21:236-242.
Hamilton, W., 1979. Tectonics of the Indonesian Region. U.S. Geol. Surv. Prof. Pap., 1078:345.

Haq, B. U., Hardenbol, J., and Vail, P. R., 1987. Chronology of fluctuating sea levels since the Triassic. Science, 235:1156-1167.

Harper, H. E., and Knoll, A. H., 1975. Silica, diatoms, and Cenozoic radiolarian evolution. Geology, 3:175-177.

Hays, J. D., Saito, T., Opdyke, N. D., and Burckle, L. H., 1969. Pliocene-Pleistocene sediments of the equatorial Pacific: their paleomagnetic, biostratigraphic, and climatic record. Geol. Soc. Am. Bull., 80:1481-1514.

Heath, G. R., 1974. Dissolved silica in deep-sea sediments. Spec. Publ., Soc. Econ. Paleontol. Mineral., 20:77-93.

Hsü, K. J., 1977. Tectonic evolution of the Mediterranean basins. In Nairn, A.E.M., Kanes, W. H., and Stehli, F. G. (Eds.), The Sea (Vol. 4A): The Ocean Basins and Margins: New York (Plenum Press): 29-75.

Hutson, W. H., 1977. Variations in planktonic foraminiferal assemblages along north-south transects in the Indian Ocean. Mar. Micropaleontol., 2:47-66.

Jousé, A. P., and Kazarina, G. H., 1974. Pleistocene diatoms from Site 262, Leg 27, DSDP. In Veevers, J. J., Heirtzler, J. R., et al. Init. Repts. DSDP, 27: Washington (U.S. Govt. Printing Office), 925945.

Kazarina, G. K., 1982. Stratigraphic distribution of diatoms in upper Miocene-lower Pliocene deposits of the Crozet Basin. Acta Geol. Acad. Sci. Hung., 25:85-96.

Keller, G., and Barron, J. A., 1983: Paleoceanographic implications of Miocene deep-sea hiatuses. Geol. Soc. Am. Bull., 94:590-613.

Kennett, J. P., Keller, G., and Srinivasan, M. S., 1985. Miocene planktonic foraminiferal biogeography and paleoceanographic development of the Indo-Pacific region. Mem. Geol. Soc. Am., 163:197236.

Kolbe, R. W., 1957. Diatoms from equatorial Indian Ocean Cores. Rep. Swed. Deep-Sea Exped., 9:3-50.

Kozlova, O. G., 1971. The main features of diatom and silicoflagellate distribution in the Indian Ocean. In Funnell, B. M., and Riedel, W. R. (Eds.), The Micropaleontology of Oceans: Cambridge (Cambridge Univ. Press), 271-275.

Leg 117 Shipboard Scientific Party, 1988. Leg 117 finds mountains, monsoons. Geotimes, March:13-16.

Leinen, M., 1979. Biogenic silica accumulation in the central equatorial Pacific and its implications for Cenozoic paleoceanography. Geol. Soc. Am. Bull., 90:(I)801-803, (II)1310-1376.

Leinen, M., Cwienk, D., Heath, G. R., Biscaye, P. E., Kolla, V., Thiede, J., and Dauphin, J. P., 1986. Distribution of biogenic silica and quartz in Recent deep-sea sediments. Geology, 14:199-203.

Lisitzin, A. P., 1972. Sedimentation in the world ocean. Spec. Publ., Soc. Econ. Paleontol. Mineral., No. 17.

1985. The silica cycle during the last ice age. Palaeogeogr., Palaeoclimatol., Palaeoecol., 50:241-270.

Martini, E., 1971. Neogene silicoflagellates from the equatorial Pacific. In Winterer, E. L., Riedel, W. R., et al., Init. Repts. DSDP, 7: Washington (U.S. Govt. Printing Office), 1695-1708.

Mikkelsen, N., 1977. On the origin of Ethmodiscus ooze. Mar. Micropaleontol., 2:35-46.

1978. Preservation of diatoms in glacial to Holocene deepsea sediments of the equatorial Pacific. Geology, 6:553-555.

Molina-Cruz, A., and Price, P., 1977. Distribution of opal and quartz on the ocean floor of the subtropical southeastern Pacific. Geology, 5:81-84.

Müller, D. W, and Schrader, H., 1989. Diatoms in the Fortuna Basin, southeast Spain: evidence for the intra-Messinian inundation. Paleoceanography, 4:75-86.

Okada, H., and Bukry, D., 1980. Supplementary modification and introduction of code numbers to the low-latitude coccolith biostratigraphic zonation (Bukry, 1973; 1975). Mar. Micropaleontol., 5:321325 .

Pokras, E. M., 1986. Preservation of fossil diatoms in Atlantic sediment cores: control by supply rate. Deep-Sea Res., 33:893-902.

Pokras, E. M., and Molfino, B., 1986. Oceanographic control of diatom abundances and species distribution in surface sediments of the tropical and southeast Atlantic. Mar. Micropaleontol., 10:165-188.

Sancetta, C. A., 1982. Diatom biostratigraphy and paleoceanography, Deep Sea Drilling Project Leg 68. In Prell, W. L., Gardner, J. V., et 
al., Init. Repts. DSDP, 68: Washington (U.S. Govt. Printing Office), 301-309.

1983. Biostratigraphic and paleoceanographic events in the eastern equatorial Pacific: results of Deep Sea Drilling Project Leg 69. In Cann, J. R., Langseth, M. G., Honnorez, J., Von Herzen, R. P., White, S. M., et al., Init. Repts. DSDP, 69: Washington (U.S. Govt. Printing Office), 311-320.

Schink, D. R., Fanning, K. A., and Pilson, M.E.Q., 1974. Dissolved silica in upper pore waters of the Atlantic Ocean floor. J. Geophys. Res., 79:2243-2250.

Schmitz, B., 1987. Barium, equatorial high productivity, and the northward wandering of the Indian continent. Paleoceanography, 2:6377.

Schrader, H. J., 1973. Cenozoic diatoms from the Northeast Pacific, Leg 18. In Kulm, L. D., von Huene, R., et al., Init. Repts. DSDP, 18: Washington (U.S. Govt. Printing Office), 673-797.

1974. Cenozoic marine planktonic diatom stratigraphy of the tropical Indian Ocean. In Fisher, R. L., Bunce, E. T., et al., Init. Repts. DSDP, 24: Washington (U.S. Govt. Printing Office), 887967.

Schrader, H. J., and Gersonde, R., 1978. Diatoms and silicoflagellates. Utrecht Micropaleontol. Bull., 17:129-176.

Schuette, G., and Schrader, H. J., 1981. Diatom taphocoenoses in the coastal upwelling area off southwest Africa. Mar. Micropaleontol., 6:131-155.

Shipboard Scientific Party, 1988a. Introduction and explanatory notes. In Ruddiman, W., Sarnthein, M., et al., Proc. ODP, Init. Repts., 108: College Station, TX (Ocean Drilling Program), 5-28.
Shipboard Scientific Party, 1988b. Explanatory notes. In Backman, J., Duncan, R. A., et al., Proc. ODP, Init. Repts., 115: College Station, TX (Ocean Drilling Program), 17-42.

Stabell, B., 1986. Variations of diatom flux in the eastern equatorial Atlantic during the last 400,000 years ("Meteor" cores 13519 and 13521). Mar. Geol., 72:305-323.

Thiede, J. G., 1981. Reworked neritic fossils in upper Mesozoic and Cenozoic central Pacific deep-sea sediments monitor sea-level changes. Science, 211:1422-1424.

Van Bennekom, A. J., and Berger, G. W., 1984. Hydrography and silica budget of the Angola Basin. Neth. J. Sea Res., 17:149-200.

Woodruff, F., and Savin, S. M., 1989. Miocene deepwater oceanography. Paleoceanography, 4:87-140.

Wright, J. D., and Thunell, R. C., 1988. Neogene planktonic foraminiferal biogeography and paleoceanography of the Indian Ocean. Micropaleontology, 34:193-216.

Wyrtki, K., 1973. Physical oceanography of the Indian Ocean. In Zeitschel, B., and Gerlach, S. A. (Eds.), The Biology of the Indian Ocean: Berlin-Heidelberg-New York (Springer-Verlag), 18-36.

Date of initial receipt: 7 July 1989

Date of acceptance: 3 January 1990

Ms 115B-157 